\title{
A review on thermo-physical properties and heat transfer applications of single and hybrid metal oxide nanofluids
}

\author{
W.H. Azmi ${ }^{1,2,3, *}$, S.N.M. Zainon ${ }^{1}$, K.A. Hamid ${ }^{1}$, R. Mamat ${ }^{1,2,3}$ \\ ${ }^{1}$ Faculty of Mechanical Engineering, Universiti Malaysia Pahang \\ 26600 Pekan, Pahang, Malaysia \\ Phone : +6094246338; Fax : +6094242202 \\ "Email: wanazmi@ump.edu.my \\ ${ }^{2}$ Automotive Engineering Centre, Universiti Malaysia Pahang \\ 26600 Pekan, Pahang, Malaysia \\ ${ }^{3}$ Centre of Excellence for Advanced Research in Fluid Flow \\ Lebuhraya Tun Razak, 26300 Kuantan, Pahang, Malaysia
}

\begin{abstract}
Numerous investigators have explored nanofluids extensively for different types of nanomaterials either the single nanoparticles or hybrid types. This is due to their advantages in thermal properties together with its contribution to the enhancement of heat transfer performance. This paper highlights a complete assessment on thermo-physical properties of single and hybrid metal oxide nanofluids and their heat transfer applications. The paper presents an overview of the thermo-physical properties characterizations namely thermal conductivity, dynamic viscosity, density and specific heat. Furthermore, summaries on the performance of forced convection heat transport and recent developments of the oxide nanofluids are presented. The numerical and experimental studies related to forced convection heat transfer using oxide nanofluids were presented. The thermal conductivity of oxide nanofluids was improved to a maximum of $40 \%$ enhancement in the literature. Meanwhile, the heat transfer augmentation up to $60 \%$ was reported by various studies. Most of the literatures confirmed the capability of nanofluids to improve the heat transfer efficiency and simultaneously insignificant increments in pressure drop. Hence, the oxide nanofluids are recommended for applications in various engineering systems.
\end{abstract}

Keywords: nanofluids; thermal conductivity; dynamic viscosity; thermo-physical properties; heat transport.

\section{INTRODUCTION}

Nanofluids can be defined as nano-sized particles with less than $100 \mathrm{~nm}$ which is suspended in conventional base fluids such as water, ethylene glycol, and oil. In the early 1990s, the nanofluids were pioneered by Masuda et al. [1] and Choi [2] with a new idea of using nanoparticles in thermal systems to develop an efficient heat transfer fluid. Subsequently, numerous studies were conducted and widely merged in engineering applications such as automotive, manufacturing process, medical, renewable energy and many more. Most of the 
fundamental studies were investigated the thermo-physical properties of nanofluids mostly on thermal conductivity and dynamic viscosity [3-5].

Common oxide nanomaterials such as Zinc oxide $(\mathrm{ZnO})$, Silicon dioxide $\left(\mathrm{SiO}_{2}\right)$, Copper oxide $(\mathrm{CuO})$, Aluminum oxide $\left(\mathrm{Al}_{2} \mathrm{O}_{3}\right)$, Titanium oxide $\left(\mathrm{TiO}_{2}\right)$, Iron oxide $\left(\mathrm{Fe}_{3} \mathrm{O}_{4}\right)$, Magnesium oxide $(\mathrm{MgO})$ and Zirconium oxide $\left(\mathrm{ZrO}_{2}\right)$ were being used in preparation of oxide nanofluids. Oxide nanoparticles have been used widely in the thermo-properties investigation and heat transfer performance evaluation of nanofluids. The oxide nanoparticles were considered in most nanofluids studies because of the production cost that is considerably lower than other types of nanomaterials. They are also commercialized and are widely used in various sectors such as automotive, coatings, filtration, army, energy, oil and gas, cosmetics, and electronics. Iron oxide or known as $\mathrm{Fe}_{3} \mathrm{O}_{4}$ has superparamagnetic properties where their magnetization properties can randomly flip directions under the influence of temperature. Meanwhile, magnetization surplus will be cancelled by thermal agitation for a condition in which the external magnetic field is removed. Thus, loss of magnetization can prevent aggregation, and hence help the stability of suspended nanoparticles in nanofluids. In addition, some advantages of Aluminum oxide or $\mathrm{Al}_{2} \mathrm{O}_{3}$ are chemically stable, mechanical strength enhancement and applicable for electrical insulating. $\mathrm{Al}_{2} \mathrm{O}_{3}$ in composite provides high barrier, fire-resistant, thermal fatigue resistance, stiffness, fracture toughness, creep resistance, resilience, and wear resistance. Meanwhile, the advantages of Silicon dioxide or $\mathrm{SiO}_{2}$ are outstanding thermal stability, attractive mechanical properties, high strength and stiffness. The nanofluids were recommended for many applications. A review for adoption of nanofluids in PEM fuel cell was done by Zakaria et al. [6]. In addition, studies related to application of nanofluids in engineering applications were undertaken by various researchers $[7,8]$.

Nanofluids have been widely explored by various investigators for different types of nanomaterials either the single nanoparticles or hybrid types. This is due to their advantages in thermal properties along with contribution to the improvement in the heat transfer performance. Currently, numerous numbers of studies were performed by various investigators mostly on oxide nanofluids. However, the review on oxide nanofluids for single nanoparticles or hybrid types and their heat transfer applications is limited in literature. Present paper is therefore aimed at reviewing the latest studies of thermo-physical properties by emphasizing on the oxide nanofluids and their heat transfer applications.

\section{NANOFLUID PREPARATION AND STABILITY}

According to Lee et al. [9], low cost, long-term stability and great fluidity are the most crucial preconditions of the nanofluids for practical applications in the heat transport system. The step of nanofluid preparation is essential before proceeding to the thermo-physical properties and heat transfer characteristics of the nanofluids. Several reviews on nanofluid preparation and stability were presented by various investigators [4-7] by providing the development on recent studies. Based on reviews by Babita et al. [10] and Suganthi and Rajan [11], the preparation of nanofluids can be summarized with the following methods:

i. One-step method: A technique which incorporate the production of nanoparticles with the synthesis of nanofluids. Example: Inert gas condensation, chemical reduction, pulsed wire evaporation and arc-submerged nanoparticle synthesis system (ASNSS). 
ii. Two-step method: Two stages of preparation are considered in this method. First, nanomaterials are produced in the form of dry powder. Then, the powdered nanomaterials are directly dispersed into the base fluid. Adoption of tools that rely either on the utilization of mechanical energy or surface chemistry or both are the key to the successful preparation of nanofluids by the two-step method. According to Manna [12], this method is suitable for preparation of oxide nanofluids.

Some special techniques are required to enhance and prolong the stability of nanofluids [10, 11] and are given by the following treatments:

i. Chemical treatment: Utilization of chemical reactant and process like adding surfactants, $\mathrm{pH}$ alteration and surface modification of the nanoparticles.

ii. Physical treatment: Employment of physical process such as magnetic stirring, ultrasonication, homogenization and mechanical milling.

The stability observation can be divided into two methods namely, the qualitative and quantitative measurement. The stability analysis of nanofluids can be conducted through qualitative methods such as sedimentation techniques and visual observation. Camera photography or submerged tray technique are usually used in the evaluation of the sedimentation. It was stated that the simplest method to observe the stability condition of nanofluids is visually. The visual approach was practiced by many investigators [13-16]. One can photograph the sample as often as possible until separation layer appears in the fluid. The sedimentation of nanoparticles was observed with time and the thickness of separation layer was recorded for further assessment of stability condition. There is no standard time for the sample to show separation layer since it can be influenced by several factors including size and shape of particles, preparation method used, and concentration of the sample $[13,15]$. In another paper, Nabil et al. [17] were considered qualitative method to evaluate the stability of their samples by using sedimentation techniques and visual observation. The samples were observed for a month and found in good stability with no evident of sedimentation.

On the other hand, the quantitative method is the most reliable technique to measure the level of nanofluid stability. It can be done through measurement of zeta potential, diffractometer and electron microscopy [18, 19]. These methods require scientific instruments and more complex equipment are expected. However, the indicative information is more reliable and accurate to establish the stability of nanofluids. Abdolbaqi et al. [20] were used FESEM with $\times 3,000,000$ magnification to evaluate the characterization of $\mathrm{Al}_{2} \mathrm{O}_{3}$ nanoparticles suspended at different ratio of water and Biogylcol (W/BG) mixture. The median particles size from the FESEM analysis was quantified at $13 \mathrm{~nm}$ and mostly spherical in shape. Similarly, Chiam et al. [21] also studied the characterization of $\mathrm{Al}_{2} \mathrm{O}_{3}$ nanoparticles but dispersed in different ratio of water and ethylene glycol (W/EG) mixture. They obtained similar average size of $13 \mathrm{~nm}$ for $\mathrm{Al}_{2} \mathrm{O}_{3}$ nanoparticles and appeared in spherical shape. In addition, some researchers tend to use relative and comparative techniques to measure the state of nanofluid stability by using Ultraviolet-Visible (UV-Vis) spectroscopy [22] and density measurements [23]. 


\section{THERMO-PHYSICAL PROPERTIES OF OXIDE NANOFLUIDS}

The measurement and estimation of thermo-physical properties of nanofluids mainly comprises the four main properties namely, thermal conductivity, viscosity, density and specific heat. These properties are essential for the determination of the overall heat transfer performance of nanofluids. The thermo-physical properties are measured using scientific instruments or estimated from the available models in literature. Several factors that affect the thermo-physical properties are such as types of materials, nanoparticle concentration, size and shape, base fluid, and operating temperature [13, 24-28]. These factors are discussed in this section by focusing on the trend and significant findings for oxide nanofluids from numerous literatures. Various studies were conducted to investigate the properties performance for single oxide nanofluids such as $\mathrm{Al}_{2} \mathrm{O}_{3}, \mathrm{SiO}_{2}, \mathrm{TiO}_{2}, \mathrm{CuO}, \mathrm{ZnO}, \mathrm{Fe}_{3} \mathrm{O}_{4}$ and $\mathrm{MgO}$ nanofluids. Meanwhile, some studies for hybrid or composite nanofluids are used in combination of the oxide nanoparticles or any other types of nanomaterials [15, 29-31]. The following section discussed in details the related studies for thermo-physical properties of oxide nanofluids.

\section{Thermal conductivity}

Hemmat Esfe et al. [32] conducted a study on thermal conductivity of $\mathrm{Al}_{2} \mathrm{O}_{3}$ nanoparticles in ethylene glycol (EG) for volume concentration of 0.2 to $5.0 \%$. The transient hot wire method by the KD2 Pro instrument was employed in the measurement of the thermal conductivity. The results indicated that the effective thermal conductivity of $\mathrm{Al}_{2} \mathrm{O}_{3} / \mathrm{EG}$ nanofluids increased with increasing nanoparticle concentration and temperature. They showed maximum enhancement up to $12.7 \%$. At higher concentrations of more than $1.0 \%$, the effect of temperature on the effective thermal conductivity was found to be more tangible. Enhancement of thermal conductivity was found due to the Brownian motion with a high rate of collision between particles. Zakaria et al. [6] used $\mathrm{Al}_{2} \mathrm{O}_{3}$ nanoparticles dispersed in several ratios for water/EG mixture from 0 to $100 \%$ by volume. The thermal conductivity of $\mathrm{Al}_{2} \mathrm{O}_{3}$ nanofluids was measured for volume concentrations of 0.1 to $0.5 \%$ and temperature of 20 ${ }^{\circ} \mathrm{C}$. A decrease in thermal conductivity was discovered when the content of EG in the mixture increased but increased with the increase of volume concentration of nanofluids. The maximum enhancement was observed for $0.5 \%$ concentration and EG content of $100 \%$.

Sonawane et al. [33] studied on thermal conductivity of $\mathrm{TiO}_{2}$ nanofluids in three base fluids of water, EG and paraffin oil. The improvement in thermal conductivity for the $\mathrm{TiO}_{2} /$ water nanofluids was found to be greater than $\mathrm{TiO}_{2} / \mathrm{EG}$ and $\mathrm{TiO}_{2} /$ paraffin oil with a maximum enhancement of $22.13 \%$. The low-viscosity fluids (water has lower viscosity than EG and paraffin oil) permit particles to interact more rapidly with one another. Therefore, the Brownian motion of nanoparticles in water based fluids is higher than others. $\mathrm{SiO}_{2}$ is a common type of oxide nanomaterial. Guo et al. [34] investigated the thermal conductivity of $\mathrm{SiO}_{2}$ nanofluids in mixture of water and EG. The EG content by volume was varied from 0 to $100 \%$. The thermal conductivity of the nanofluids was conducted for $0.3 \%$ weight concentration and temperature of 25 to $45{ }^{\circ} \mathrm{C}$. The findings showed that the thermal conductivity decreased with increasing EG content at a constant temperature. In addition, the thermal conductivity of $\mathrm{SiO}_{2}$ nanofluids increased with increasing temperature for similar EG content. 
$\mathrm{CuO}$ is also a common oxide nanoparticle and used in preparing single and hybrid nanofluids. Agarwal et al. [35] performed a study on thermal conductivity of $\mathrm{CuO}$ in base fluid of water, EG and engine oil. The investigation was performed at temperature of 10 to $70{ }^{\circ} \mathrm{C}$ and volume concentration of 0.25 to $2.0 \%$. According to their results, the thermal conductivity enhancement was observed up to 40, 27 and 19\%, respectively for $\mathrm{CuO}$ in water, EG and engine oil. Nemade and Waghuley [36] investigated a novel approach for thermal conductivity enhancement with $\mathrm{CuO}$ /water nanofluids. The evaluation was conducted at $0.5 \%$ concentration for temperature of 30 to $80{ }^{\circ} \mathrm{C}$ and probe sonication time of 15 to 60 minutes. They found that $18 \%$ enhancement of thermal conductivity was achieved for 60 minutes sonication time in comparison to the base fluid. Furthermore, the thermal conductivity of nanofluids for all sonication time was enhanced with increasing temperature. This was the result of the incessant collision between particles and base fluid, as well as influenced by large Brownian viscosity. The study also concluded that the $\mathrm{CuO}$ nanofluid exhibits good thermal and heat transfer characteristics and hence it was recommended for renewable energy applications.

Hybrid and composite nanofluids of oxide nanoparticles were investigated by various researchers. Ho et al. [37] obtained 13\% enhancement of thermal conductivity for $\mathrm{Al}_{2} \mathrm{O}_{3}+\mathrm{MEPCM}$ in water nanofluids. The nanofluids was prepared for 2 to $10 \%$ weight concentration. The thermal conductivity was measured by using KD2 Pro thermal property analyzer at various temperatures of 25 to $40{ }^{\circ} \mathrm{C}$. In another paper, Suresh et al. [38] prepared hybrid nanofluids with a combination of $\mathrm{Al}_{2} \mathrm{O}_{3}$ with $\mathrm{Cu}$ nanoparticles. They were considered 90:10 ratio of $\mathrm{Al}_{2} \mathrm{O}_{3}$ to $\mathrm{Cu}$ dispersed in water. The thermal conductivity was measured at a constant temperature of $32{ }^{\circ} \mathrm{C}$. The highest enhancement was observed up to $12.11 \%$ for $2 \%$ volume concentrations. Further, Charab et al. [39] used combination of $\mathrm{Al}_{2} \mathrm{O}_{3}$ and $\mathrm{TiO}_{2}$ nanoparticles in water to prepare composite nanofluids. The average size of particle, $\mathrm{pH}$ and concentration were given by $20 \mathrm{~nm}, 3.8$ and $1.0 \%$, respectively. They measured the thermal conductivity using the transient hot wire method at constant temperature of $25^{\circ} \mathrm{C}$. The results revealed that the stability of the sample became the major contribution to the non-linearity in thermal conductivity of composite nanofluids. In another paper, Nine et al. [40] combined the $\mathrm{Al}_{2} \mathrm{O}_{3}$ and MWCNT nanoparticles to prepare hybrid nanofluids for concentrations of 1.0 to $6.0 \mathrm{wt} . \%$. They found that the thermal conductivity enhancement of hybrid nanofluids with spherical shape particles was lesser than cylindrical shape particles.

Toghraie et al. [41] measured the thermal conductivity of $\mathrm{TiO}_{2}+\mathrm{Zn}$ in $\mathrm{EG}$ nanofluids for volume concentrations of 0.1 to $3.5 \%$ and temperatures of 25 to $50{ }^{\circ} \mathrm{C}$. They observed that the thermal conductivity of nanofluids increased significantly with increasing temperature and volume concentration of nanofluids. The maximum enhancement of $32 \%$ was obtained with $3.5 \%$ volume concentration and $50{ }^{\circ} \mathrm{C}$ of temperature. In another paper, Hemmat Esfe et al. [32] used $\mathrm{CuO}$ and $\mathrm{TiO}_{2}$ nanoparticles in water/EG mixture. The thermal conductivity of the hybrid nanofluids was measured for temperature range of 30 to $60{ }^{\circ} \mathrm{C}$. Maximum enhancement was obtained for $2.0 \%$ volume concentration and $60{ }^{\circ} \mathrm{C}$ of temperature. Later, Megatif et al. [42] combined $\mathrm{TiO}_{2}$ and CNT nanoparticles to prepare hybrid nanofluids with weight concentrations of 0.1 to $0.2 \%$. The thermal conductivity was measured at 25 to $40{ }^{\circ} \mathrm{C}$ by using the transient hot wire method of the KD2 Pro analyzer. They found that the augmentation in thermal conductivity was observed up to $20.5 \%$ for $0.2 \%$ weight concentration and temperature of $25^{\circ} \mathrm{C}$. Batmunkh et al. [43] procured silver $(\mathrm{Ag})$ and $\mathrm{TiO}_{2}$ nanoparticles in the preparation of hybrid nanofluids. In their study, they used 
a combination of small Ag nanoparticle size $(15 \mathrm{~nm})$ with larger particle size of $\mathrm{TiO}_{2}(300$ $\mathrm{nm})$. The thermal conductivity of the hybrid nanofluids was measured at temperatures of 15 to $40{ }^{\circ} \mathrm{C}$. They concluded that the thermal conductivity of $\mathrm{TiO}_{2}$ nanofluids improved by introducing the flattened Ag nanoparticles.

Madhesh et al. [44] prepared hybrid nanofluids of $\mathrm{TiO}_{2}+\mathrm{Cu}$ with the average size of $55 \mathrm{~nm}$. The measurement of the thermal conductivity was taken by using the laser flash method for volume concentrations of 0.1 to $2.0 \%$ and temperature ranging from 30 to $90{ }^{\circ} \mathrm{C}$. They found that the thermal conductivity was 1.065 times higher than water base fluids. In another study by Baghbanzadeh et al. [45], hybrid nanoparticles with a combination of $\mathrm{SiO}_{2}$ and MWCNT were prepared for two different ratios of 80:20 and 50:50. The thermal conductivity of the hybrid nanofluids was measured for 0.1 to $1.0 \%$ weight concentration at temperature of 27 and $40{ }^{\circ} \mathrm{C}$. Their findings revealed that the enhancement in thermal conductivity was found to a maximum of $23.3 \%$ for temperature of $40{ }^{\circ} \mathrm{C}$ and $1.0 \%$ volume concentration. On the other hand, Nabil et al. [30] investigated the thermo-physical properties of $\mathrm{SiO}_{2}+\mathrm{TiO}_{2}$ nanoparticles in water/EG mixture. They measured the thermal conductivity of hybrid nanofluids for 0.5 to $3.0 \%$ volume concentration and temperature of 30 to $80{ }^{\circ} \mathrm{C}$. The maximum enhancement of $22.8 \%$ was obtained at $3.0 \%$ volume concentration and temperature of $80^{\circ} \mathrm{C}$.

Baby and Sundara [46] studied the synthesis and transport properties of $\mathrm{CuO}$ nanoparticles with decorated graphene (HEG) in water-EG mixture. The thermal conductivity of the hybrid nanofluids was measured at a constant temperature of $25^{\circ} \mathrm{C}$. The results displayed that the improvement of thermal conductivity was approximately $28 \%$ for $0.05 \%$ volume concentration. Meanwhile, Nine et al. [47] prepared hybrid nanofluids with both nanoparticles from copper element and dispersed in water. They used $\mathrm{Cu}+\mathrm{Cu}_{2} \mathrm{O}$ with $30 \mathrm{~nm}$ average diameter. They only studied for $2.0 \%$ weight concentration and the thermal conductivity was measured at temperature of 15 to $40{ }^{\circ} \mathrm{C}$. Their study revealed that the thermal conductivity of the hybrid nanofluids improved further with 1.014 times higher than base fluid. Table 1 shows the summary of previous work regarding the thermal conductivity enhancement of oxide nanofluids for single type and hybrid type nanofluids. 
Table 1. Summary of thermal conductivity enhancement for oxide nanofluids.

\begin{tabular}{|c|c|c|c|}
\hline $\begin{array}{l}\text { Nanofluids } \\
\text { (Range of } \\
\text { concentratio } \\
\text { n) } \\
\end{array}$ & $\begin{array}{l}\text { Measurement } \\
\text { method / } \\
\text { Instrument } \\
\text { (Temperature) }\end{array}$ & $\begin{array}{c}\text { Significance enhancement }(\%) / \\
\text { Findings }\end{array}$ & References \\
\hline $\begin{array}{c}\mathrm{Al}_{2} \mathrm{O}_{3} \text { in } \mathrm{EG} \\
(0.2-5.0 \\
\text { vol. } \%)\end{array}$ & $\begin{array}{l}\text { THW / KD2 Pro } \\
\left(24-50{ }^{\circ} \mathrm{C}\right)\end{array}$ & Maximum enhancement $(12.7 \%)$ & $\begin{array}{l}\text { Hemmat Esfe } \\
\text { et al. [32] }\end{array}$ \\
\hline $\begin{array}{c}\mathrm{Al}_{2} \mathrm{O}_{3} \text { in } \\
\mathrm{W} / \mathrm{EG} \\
(0.1- \\
0.5 \text { vol. } \%)\end{array}$ & $\begin{array}{l}\text { THW / KD2 Pro } \\
\left(20^{\circ} \mathrm{C}\right)\end{array}$ & $\begin{array}{l}\text { Maximum enhancement at } \phi= \\
0.5 \% \text { for EG content at } 100 \%\end{array}$ & $\begin{array}{c}\text { Zakaria et al. } \\
{[6]}\end{array}$ \\
\hline $\begin{array}{c}\mathrm{TiO}_{2} \text { in } \\
\text { water, EG, } \\
\text { paraffin oil } \\
(1.0-6.0 \\
\text { vol. } \%)\end{array}$ & $\begin{array}{l}\text { THW / KD2 Pro } \\
\text { (room } \\
\text { temperature) }\end{array}$ & $\begin{array}{l}\text { Maximum enhancement }(22.13 \%) \\
\text { for } \mathrm{TiO}_{2} / \text { water }\end{array}$ & $\begin{array}{c}\text { Sonawane et } \\
\text { al. [33] }\end{array}$ \\
\hline $\begin{array}{c}\mathrm{SiO}_{2} \text { in } \\
\mathrm{EG} / \mathrm{W}(0.3 \\
\text { wt. } \%)\end{array}$ & $\begin{array}{l}\text { THW / TC 3020L } \\
\quad\left(25-45^{\circ} \mathrm{C}\right)\end{array}$ & $\begin{array}{l}\text { At fixed EG content, the thermal } \\
\text { conductivity of nanofluids } \\
\text { increased with increasing of } \\
\text { temperature }\end{array}$ & $\begin{array}{l}\text { Guo et al. } \\
\text { [34] }\end{array}$ \\
\hline $\begin{array}{c}\mathrm{CuO} \text { in } \\
\text { water, } \mathrm{EG}, \\
\text { engine oil } \\
(0.25-2.0 \\
\text { vol. } \%) \\
\end{array}$ & $\begin{array}{l}\text { THW / KD2 Pro } \\
\left(10-70^{\circ} \mathrm{C}\right)\end{array}$ & $\begin{array}{l}\text { Enhancement: } 40 \%, 27 \% \text { and } 19 \% \text {, } \\
\text { for } \mathrm{CuO} \text { in water, EG and engine } \\
\text { oil, respectively }\end{array}$ & $\begin{array}{l}\text { Agarwal et } \\
\text { al. [35] }\end{array}$ \\
\hline $\begin{array}{l}\mathrm{CuO} \text { in water } \\
(0.5 \text { vol. } \%)\end{array}$ & $\begin{array}{l}\text { THW / KD2 Pro } \\
\left(30-80^{\circ} \mathrm{C}\right)\end{array}$ & $\begin{array}{l}\text { Enhancement }(18 \%) \text { at } 60 \text { minutes } \\
\text { sonication time }\end{array}$ & $\begin{array}{c}\text { Nemade and } \\
\text { Waghuley } \\
\text { [36] }\end{array}$ \\
\hline $\begin{array}{l}\mathrm{Al}_{2} \mathrm{O}_{3}+\mathrm{MEP} \\
\mathrm{CM} \text { in water } \\
(2-10 \text { wt. } \%)\end{array}$ & $\begin{array}{l}\text { THW / KD2 Pro } \\
\left(25-40{ }^{\circ} \mathrm{C}\right)\end{array}$ & $\begin{array}{l}\text { Maximum enhancements }(13 \%) \text { at } \\
\text { PCM suspension } \omega_{\mathrm{pcm}} 10 \mathrm{wt} . \% \text {, } \\
\text { nanoparticles } \omega_{\mathrm{np}} 10 \% \text { weight } \\
\text { concentration }\end{array}$ & Ho et al. [37] \\
\hline $\begin{array}{l}\mathrm{Al}_{2} \mathrm{O}_{3}+\mathrm{Cu} \text { in } \\
\text { water }(0.1- \\
2.0 \text { vol. } \%)\end{array}$ & $\begin{array}{c}\text { THW / KD2 Pro } \\
\left(32^{\circ} \mathrm{C}\right)\end{array}$ & $\begin{array}{l}\text { Maximum enhancement }(12.11 \%) \\
\text { at } \phi=2 \%\end{array}$ & $\begin{array}{c}\text { Suresh et al. } \\
\text { [38] }\end{array}$ \\
\hline $\begin{array}{l}\mathrm{Al}_{2} \mathrm{O}_{3}+\mathrm{TiO}_{2} \\
\text { in water } \\
(1.0 \text { vol. } \%)\end{array}$ & $\begin{array}{l}\text { THW / - } \\
\left(25^{\circ} \mathrm{C}\right)\end{array}$ & $\begin{array}{l}\text { Nonlinear behavior was observed } \\
\text { for thermal conductivity of } \\
\text { nanofluids versus FVC of } \mathrm{TiO}_{2}\end{array}$ & $\begin{array}{c}\text { Charab et al. } \\
\text { [39] }\end{array}$ \\
\hline
\end{tabular}




\begin{tabular}{|c|c|c|c|}
\hline $\begin{array}{l}\mathrm{Al}_{2} \mathrm{O}_{3}+\mathrm{MWC} \\
\mathrm{NT}(1.0-6.0 \\
\text { wt. } \%)\end{array}$ & - & $\begin{array}{l}\text { Hybrid nanofluids with spherical } \\
\text { particles performed lower } \\
\text { increment in thermal conductivity } \\
\text { than cylindrical shape particles }\end{array}$ & $\begin{array}{l}\text { Nine et al. } \\
\quad[40]\end{array}$ \\
\hline $\begin{array}{l}\mathrm{ZnO}+\mathrm{TiO}_{2} \text { in } \\
\mathrm{EG}(0.1- \\
3.5 \text { vol. } \%)\end{array}$ & $\begin{array}{l}\text { THW / KD2 Pro } \\
\left(25-50^{\circ} \mathrm{C}\right)\end{array}$ & $\begin{array}{l}\text { Maximum enhancement }(32 \%) \text { at } \phi \\
=3.5 \% \text { and } 50{ }^{\circ} \mathrm{C}\end{array}$ & $\begin{array}{l}\text { Toghraie et } \\
\text { al. [41] }\end{array}$ \\
\hline $\begin{array}{c}\mathrm{TiO}_{2}+\mathrm{CuO} \text { in } \\
\text { water/EG } \\
(1.0-2.0 \\
\text { vol. } \%)\end{array}$ & $\begin{array}{l}\text { THW / KD2 Pro } \\
\left(30-60^{\circ} \mathrm{C}\right)\end{array}$ & $\begin{array}{l}\text { Correlation models show excellent } \\
\text { agreement with experimental } \\
\text { results }\end{array}$ & $\begin{array}{l}\text { Hemmat Esfe } \\
\text { et al. [32] }\end{array}$ \\
\hline $\begin{array}{l}\mathrm{TiO}_{2}+\mathrm{CNT} \text { in } \\
\text { water }(0.1- \\
0.2 \text { wt. } \%)\end{array}$ & $\begin{array}{l}\text { THW / KD2 Pro } \\
\left(25-40^{\circ} \mathrm{C}\right)\end{array}$ & $\begin{array}{l}\text { Maximum enhancement }(20.5 \%) \text { at } \\
\phi=0.2 \% \text { and } 25{ }^{\circ} \mathrm{C}\end{array}$ & $\begin{array}{c}\text { Megatif et al. } \\
\text { [42] }\end{array}$ \\
\hline $\begin{array}{l}\mathrm{TiO}_{2}+\mathrm{Ag} \text { in } \\
\text { water }(1.0- \\
3.0 \text { wt. } \%)\end{array}$ & $\begin{array}{c}\text { THW / } \\
\text { LAMBDA } \\
\text { System } \\
\left(15-40^{\circ} \mathrm{C}\right)\end{array}$ & $\begin{array}{l}\text { Flattened "Ag" particles can be } \\
\text { used to enhance thermal } \\
\text { conductivity }\end{array}$ & $\begin{array}{l}\text { Batmunkh et } \\
\text { al. [43] }\end{array}$ \\
\hline $\begin{array}{c}\mathrm{TiO}_{2}+\mathrm{Cu} \text { in } \\
\text { water } \\
(0.1-2.0 \\
\text { vol. } \%)\end{array}$ & $\begin{array}{c}\text { Laser flash / } \\
\text { NETZSCH LFA } \\
447 \text { NanoFlash } \\
\quad\left(30-90^{\circ} \mathrm{C}\right)\end{array}$ & $\begin{array}{l}\text { Maximum enhancement of } 1.065 \\
\text { higher than base fluid }\end{array}$ & $\begin{array}{l}\text { Madhesh et } \\
\text { al. [44] }\end{array}$ \\
\hline $\begin{array}{l}\mathrm{SiO}_{2}+\mathrm{MWC} \\
\mathrm{NT} \text { in water } \\
(0.1-1.0 \\
\text { wt. } \%)\end{array}$ & $\begin{array}{l}\text { THW / KD2 Pro } \\
\left(27 / 40^{\circ} \mathrm{C}\right)\end{array}$ & $\begin{array}{l}\text { Maximum enhancement }(23.3 \%) \text { at } \\
\phi=1.0 \% \text { and } 40^{\circ} \mathrm{C}\end{array}$ & $\begin{array}{l}\text { Baghbanzade } \\
\text { h et al. [45] }\end{array}$ \\
\hline $\begin{array}{c}\mathrm{SiO}_{2}+\mathrm{TiO}_{2} \text { in } \\
\text { water/EG } \\
(0.5-3.0 \\
\text { vol. } \%)\end{array}$ & $\begin{array}{l}\text { THW / KD2 Pro } \\
\left(30-80^{\circ} \mathrm{C}\right)\end{array}$ & $\begin{array}{l}\text { Maximum enhancement }(22.8 \%) \text { at } \\
\phi=3.0 \% \text { and } 80^{\circ} \mathrm{C}\end{array}$ & $\begin{array}{l}\text { Nabil et al. } \\
\text { [30] }\end{array}$ \\
\hline $\begin{array}{c}\mathrm{CuO}+\mathrm{HEG} \text { in } \\
\text { water/EG }\end{array}$ & $\left(25^{-} \mathrm{C}\right)$ & $\begin{array}{l}\text { Maximum enhancement (28\%) at } \phi \\
=0.05 \% \text { and } 25{ }^{\circ} \mathrm{C}\end{array}$ & $\begin{array}{c}\text { Baby and } \\
\text { Sundara [46] }\end{array}$ \\
\hline $\begin{array}{l}\mathrm{Cu}+\mathrm{Cu}_{2} \mathrm{O} \text { in } \\
\text { water } \\
(0.3 \text { wt. } \%)\end{array}$ & $\left(15-40^{\circ} \mathrm{C}\right)$ & $\begin{array}{l}\text { Maximum enhancement of } 1.014 \\
\text { times }\end{array}$ & $\begin{array}{l}\text { Nine et al. } \\
\quad[47]\end{array}$ \\
\hline
\end{tabular}

\section{Dynamic viscosity}

Hamid et al. [48] carried out an experiment on dynamic viscosity of $\mathrm{Al}_{2} \mathrm{O}_{3}$ nanofluids for 0.5 to $2.0 \%$ volume concentration. They studied the viscosity measurement for three different ratios of water-EG base fluid $(60: 40,50: 50,40: 60)$ and at various temperatures of 30 to 70 
${ }^{\circ} \mathrm{C}$. The findings revealed that the viscosity of $\mathrm{Al}_{2} \mathrm{O}_{3} / \mathrm{EG}$ nanofluids exhibit an increasing trend when particle loading increased but decreased exponentially with increasing temperature. In another paper, Anoop et al. [49] investigated the rheological behavior of $\mathrm{Al}_{2} \mathrm{O}_{3}$ nanoparticles in silicone oil. The measurement was undertaken at room temperature with various pressures for up to $100 \mathrm{MPa}$ and different shear rates of 5 to $1021 \mathrm{~s}^{-1}$. The weight concentrations of the nanofluids were prepared for 2.0 to $8.0 \%$. They found that the nanofluids behaved as a non-Newtonian fluid within the range of the concentration in their study. In addition, the nanofluids was observed to have shear-thinning behavior at higher shear rates and within all pressures. The critical shear rate (when shear thinning occurs) was found to be significantly affected by the particle loading.

Dynamic viscosity measurements of $\mathrm{TiO}_{2}$ nanoparticles in Bioglycol-water (BG/W) mixture was undertaken by Abdolbaqi et al. [50]. The nanofluids was prepared for volume concentrations of 0.5 to 2.0\%. The base fluid ratios of BG/W were given by 20:80 and 30:70. The measurement was conducted for temperatures of 30 to $80{ }^{\circ} \mathrm{C}$. The viscosity of $\mathrm{TiO}_{2}$ in BG/W nanofluids increased with increasing concentration but decreased with increasing temperature. The maximum viscosity rise was obtained at 1.53 times higher than the base fluid at $2.0 \%$ concentration, temperature of $70{ }^{\circ} \mathrm{C}$ and base ratio of 30:70. Later, Khedkar et al. [51] performed measurements at room temperature for viscosity evaluation of $\mathrm{TiO}_{2}$ nanoparticles in EG based nanofluids. The $\mathrm{TiO}_{2} / \mathrm{EG}$ nanofluids was prepared for up to $7.0 \%$ volume concentration. The results indicated that the viscosity linearly rose with increasing of volume concentration. The nanofluids was confirmed to have Newtonian behavior with the shear thinning nature.

In another paper, Abdolbaqi et al. [50] measured the dynamic viscosity for $\mathrm{SiO}_{2}$ nanoparticles in BG/W mixture for two ratios of 20:80 and 30:70. They prepared the nanofluids for volume concentrations of 0.5 to $2.0 \%$ and measured the viscosity at temperature of 30 to $80{ }^{\circ} \mathrm{C}$. The maximum enhancement of $\mathrm{SiO}_{2}$ nanofluids with 1.38 times higher than the base fluid was obtained for 2.0\% volume concentration, 30:70 (BG/W) base ratio and temperature of $70{ }^{\circ} \mathrm{C}$. Żyła and $\mathrm{Fal}$ [52] conducted a study on viscosity of $\mathrm{SiO}_{2} / \mathrm{EG}$ at a constant temperature of $25^{\circ} \mathrm{C}$. The sample of nanofluids were prepared for 1.0 to $5.0 \%$ mass concentrations. They discovered that the nanofluids exhibited as Newtonian fluids in the range of study and increased linearly with concentration. The maximum increment of viscosity was observed at 5\% mass concentration for up to 1.3905 times greater than the base fluid.

Ghasemi and Karimipour [53] investigated the viscosity for $\mathrm{CuO}$ nanoparticles in liquid paraffin. They prepared the nanofluids for 0.25 to $6.0 \%$ weight concentration. The viscosity was measured at temperatures of 25 to $100{ }^{\circ} \mathrm{C}$ with variations of shear rate from 13 to $159 \mathrm{~s}^{-1}$. They found that the enhancement of nanoparticle load lead to viscosity increments from 55 to $60 \%$ in the range of study. Inversely, the rise in temperature resulted in viscosity decrement. The viscosity of $\mathrm{CuO}$ /paraffin nanofluids increased for $1.5 \%$ concentration. Meanwhile, the change in viscosity was observed not highly tangible for concentrations below 1.5\%. Akhavan Behabadi et al. [54] used $\mathrm{ZnO}$ nanoparticles in EG to investigate the viscosity behavior. The weight concentration and temperatures were varied from 1.75 to $10.5 \%$ and 15 to $55^{\circ} \mathrm{C}$, respectively. Similar trends were observed by them with the viscosity increasing with increase of concentration, but decreasing with increase of temperature. In addition, the rheological evaluation of $\mathrm{ZnO} / \mathrm{EG}$ nanofluids behaved as Newtonian in the range of study. 
For the case of hybrid nanofluids, Asadi and Asadi [55] conducted an experimental study on viscosity of MWCNT+ZnO in engine oil for concentrations of 0.125 to $1.0 \%$. The viscosity measurement was conducted at temperatures of 5 to $55^{\circ} \mathrm{C}$. The outcomes revealed that the viscosity increased up to $45 \%$ with increasing concentration. Meanwhile, the dynamic viscosity of the nanofluids decreased by $85 \%$ with increasing temperature. The nanofluids also showed a Newtonian behavior within the scope of concentration and temperature study. In another study, Soltani and Akbari [56] measured the viscosity for $\mathrm{MgO}+\mathrm{MWCNT}$ hybrid nanoparticles dispersed in EG for volume concentrations up to $1.0 \%$. The measurement of viscosity was conducted at temperatures of 30 to $60{ }^{\circ} \mathrm{C}$. They found that the hybrid $\mathrm{MgO}+\mathrm{MWCNT}$ nanofluids behaved as Newtonian fluid in the range of study. A similar trend was observed by them for viscosity increments up to $168 \%$ with increasing concentration.

Akilu et al. [57] investigated the viscosity of three hybrid nanoparticles of $\mathrm{TiO}_{2}+\mathrm{CuO}+\mathrm{C}$ in EG based fluids. The viscosity was measured at temperatures of 30 to 60 ${ }^{\circ} \mathrm{C}$ and volume concentrations of 0.5 to $2.0 \%$. The hybrid nanofluids were confirmed to behave as Newtonian fluid by investigating the rheological behavior. Furthermore, the viscosity of the hybrid nanofluids was observed to increase as the concentration increased and enhanced to $80 \%$ maximum at $2.0 \%$ volume concentration. In another study for hybrid nanofluids, Nabil et al. [30] measured the viscosity for $\mathrm{TiO}_{2}+\mathrm{SiO}_{2}$ nanoparticles in water/EG mixture. The viscosity measurement was performed at temperatures of 30 to $80{ }^{\circ} \mathrm{C}$ and volume concentrations of 0.5 to $3.0 \%$. The results indicated that the viscosity was influenced by concentration and temperature. The highest average relative viscosity of $\mathrm{TiO}_{2}+\mathrm{SiO}_{2}$ nanofluids was obtained for up to $62.5 \%$ increment for $3.0 \%$ volume concentration. The Newtonian behavior also was observed by them for $\mathrm{TiO}_{2}+\mathrm{SiO}_{2}$ nanofluids in the range of study.

Shahsavar and Bahiraei [58] evaluated the dynamic viscosity for $\mathrm{Fe}_{3} \mathrm{O}_{4}+\mathrm{CNT}$ hybrid nanofluids. They used different concentrations for both nanoparticle components in the hybrid nanofluids. For instance, the concentration for $\mathrm{Fe}_{3} \mathrm{O}_{4}$ nanoparticles varied from 0.1 to $0.9 \%$ and 0 to $1.35 \%$ for CNT nanoparticles. They found that the viscosity for $\mathrm{Fe}_{3} \mathrm{O}_{4}+\mathrm{CNT}$ hybrid nanofluids decreased with the increment of shear rate, hence exhibited as nonNewtonian behavior. The viscosity increased with increasing of CNT or $\mathrm{Fe}_{3} \mathrm{O}_{4}$ concentration and decreased with increasing of hybrid nanofluid temperature. Table 2 shows the summary of previous work regarding the dynamic viscosity measurements of oxide nanofluids for single type and hybrid type nanofluids. 
Table 2. Summary of dynamic viscosity measurements for oxide nanofluids.

\begin{tabular}{|c|c|c|c|}
\hline $\begin{array}{l}\text { Nanofluids } \\
\text { (Range of } \\
\text { concentration) }\end{array}$ & $\begin{array}{l}\text { Measurement } \\
\text { method / } \\
\text { Instrument } \\
\text { (Temperature) }\end{array}$ & Significance findings & References \\
\hline $\begin{array}{l}\mathrm{Al}_{2} \mathrm{O}_{3} \text { in } \mathrm{W} / \mathrm{EG} \\
(0.5-2.0 \text { vol. } \%)\end{array}$ & $\begin{array}{l}\text { Rotational spindle / } \\
\text { Brookfield } \\
\text { Rheometer (30-70 } \\
\left.{ }^{\circ} \mathrm{C}\right) \\
\end{array}$ & $\begin{array}{l}\text { Viscosity increased with the increased of } \\
\text { particle loading but decreased } \\
\text { exponentially with the increased of } \\
\text { temperature }\end{array}$ & $\begin{array}{l}\text { Hamid et } \\
\text { al. [48] }\end{array}$ \\
\hline $\begin{array}{l}\mathrm{Al}_{2} \mathrm{O}_{3} \text { in silicone } \\
\text { oil } \\
(2.0-8.0 \mathrm{wt} . \%)\end{array}$ & $\begin{array}{c}\text { Rotor-bob } \\
\text { geometry / } \\
\text { Chandler } \\
\text { Viscometer (Room } \\
\text { temperature) }\end{array}$ & $\begin{array}{l}\text { At higher shear rate within all the } \\
\text { pressures, the nanofluids have shear- } \\
\text { thinning behavior. Classification: } \\
\text { Newtonian }\end{array}$ & $\begin{array}{l}\text { Anoop et } \\
\text { al. [49] }\end{array}$ \\
\hline $\begin{array}{l}\mathrm{TiO}_{2} \text { in } \mathrm{BG} / \mathrm{W} \\
(0.5-2.0 \text { vol. } \%)\end{array}$ & $\begin{array}{l}\text { Rotational spindle / } \\
\text { Brookfield } \\
\text { Rheometer (30-80 } \\
\left.{ }^{\circ} \mathrm{C}\right)\end{array}$ & $\begin{array}{l}\text { Viscosity increased with the increasing } \\
\text { of concentration but decreased with the } \\
\text { increasing of temperature. } \\
\text { Maximum enhancement with } 1.53 \text { times } \\
\text { at } \phi=2.0 \% \text { and } 70{ }^{\circ} \mathrm{C} \text { for ratio } 30: 70\end{array}$ & $\begin{array}{l}\text { Abdolbaqi } \\
\text { et al. [50] }\end{array}$ \\
\hline $\begin{array}{c}\mathrm{TiO}_{2} \text { in } \mathrm{EG} \\
(0-7.0 \text { vol. } \%)\end{array}$ & $\begin{array}{l}\text { Rotational / AR-G2 } \\
\text { Rheometer } \\
\text { (Room } \\
\text { temperature) }\end{array}$ & $\begin{array}{l}\text { Viscosity linearly increased with volume } \\
\text { concentration. } \\
\text { Newtonian. }\end{array}$ & $\begin{array}{l}\text { Khedkar et } \\
\text { al. [51] }\end{array}$ \\
\hline $\begin{array}{l}\mathrm{SiO}_{2} \text { in } \mathrm{BG} / \mathrm{W} \\
(0.5-2.0 \text { vol. } \%)\end{array}$ & $\begin{array}{l}\text { Rotational spindle / } \\
\text { Brookfield } \\
\text { Rheometer (30-80 } \\
\left.{ }^{\circ} \mathrm{C}\right)\end{array}$ & $\begin{array}{l}\text { Viscosity increased with the increasing } \\
\text { of concentration but decreased with the } \\
\text { increasing of temperature. } \\
\text { Maximum enhancement with } 1.38 \text { times } \\
\text { at } \phi=2.0 \% \text { and } 70{ }^{\circ} \mathrm{C} \text { for ratio } 30: 70\end{array}$ & $\begin{array}{l}\text { Abdolbaqi } \\
\text { et al. [50] }\end{array}$ \\
\hline $\begin{array}{c}\mathrm{SiO}_{2} \text { in } \mathrm{EG} \\
(1.0-5.0 \mathrm{wt} . \%)\end{array}$ & $\begin{array}{l}\text { Rotational / } \\
\text { HAAKE MARS } 2 \\
\text { Rheometer } \\
\left(25^{\circ} \mathrm{C}\right)\end{array}$ & $\begin{array}{l}\text { Viscosity linearly increased with the } \\
\text { increased of nanoparticles concentration. } \\
\text { Maximum enhancement with } 1.3905 \\
\text { times at } \phi=5 \% \text {. Classification: } \\
\text { Newtonian }\end{array}$ & $\begin{array}{l}\text { Żyła and } \\
\text { Fal [52] }\end{array}$ \\
\hline $\begin{array}{c}\mathrm{CuO} \text { in liquid } \\
\text { paraffin }(0.25-6.0 \\
\text { wt. } \%)\end{array}$ & $\begin{array}{l}\text { Rotational spindle / } \\
\text { Brookfield } \\
\text { Rheometer }\left(25^{\circ} \mathrm{C}\right)\end{array}$ & $\begin{array}{l}\text { Maximum enhancement }(55-60 \%) \text {. } \\
\text { Rise in temperature resulted in viscosity } \\
\text { decrement. } \\
\text { At } \phi<1.5 \% \text {, the change in viscosity is } \\
\text { not highly tangible }\end{array}$ & $\begin{array}{l}\text { Ghasemi } \\
\text { and } \\
\text { Karimipour } \\
\text { [53] }\end{array}$ \\
\hline $\begin{array}{c}\mathrm{ZnO} \text { in } \mathrm{EG} \\
(1.75-10.5 \text { wt.\%) }\end{array}$ & $\begin{array}{l}\text { Rotation / Kinexus } \\
\text { Rheometer } \\
\quad\left(15-55^{\circ} \mathrm{C}\right)\end{array}$ & $\begin{array}{l}\text { Viscosity increased with the increasing in } \\
\text { concentration, but decreased with the } \\
\text { increasing of temperature. Classification: } \\
\text { Newtonian. }\end{array}$ & $\begin{array}{l}\text { Akhavan } \\
\text { Behabadi et } \\
\text { al. [54] }\end{array}$ \\
\hline
\end{tabular}




\begin{tabular}{|c|c|c|c|}
\hline $\begin{array}{c}\mathrm{ZnO}+\mathrm{MWCNT} \\
\text { in engine oil } \\
(0.125-1.0 \text { vol. } \%)\end{array}$ & $\begin{array}{c}\text { Rotation / } \\
\text { Brookfield cone \& } \\
\text { plate Viscometer } \\
\left(5-55^{\circ} \mathrm{C}\right) \\
\end{array}$ & $\begin{array}{l}\text { Increment of } 45 \% \text { with increasing } \\
\text { concentration. } \\
\text { Decrement of } 85 \% \text { with increasing of } \\
\text { temperature. Classification: Newtonian. }\end{array}$ & $\begin{array}{l}\text { Asadi and } \\
\text { Asadi [55] }\end{array}$ \\
\hline $\begin{array}{c}\mathrm{MgO}+\mathrm{MWCNT} \\
\text { in EG } \\
(0-1.0 \mathrm{vol} . \%)\end{array}$ & $\begin{array}{l}\text { Rotation / } \\
\text { Brookfield } \\
\text { Viscometer } \\
\left(30-60^{\circ} \mathrm{C}\right)\end{array}$ & $\begin{array}{l}\text { Viscosity increased by } 168 \% \text { with } \\
\text { increasing concentration. } \\
\text { However, viscosity is decreased with the } \\
\text { increasing of temperature. Classification: } \\
\text { Newtonian. }\end{array}$ & $\begin{array}{l}\text { Soltani and } \\
\text { Akbari [56] }\end{array}$ \\
\hline $\begin{array}{c}\mathrm{TiO}_{2}+\mathrm{CuO}+\mathrm{C} \text { in } \\
\mathrm{EG}(0.5-2.0 \\
\text { vol. } \%)\end{array}$ & $\begin{array}{c}\text { Rotation / Physica } \\
\text { MCR302 } \\
\text { Rheometer (30-60 } \\
\left.{ }^{\circ} \mathrm{C}\right)\end{array}$ & $\begin{array}{l}\text { Viscosity increased with the increased of } \\
\text { concentration. } \\
\text { Maximum enhancement }(80 \%) \text { at } \phi= \\
2.0 \% \text {. } \\
\text { Classification: Newtonian. }\end{array}$ & $\begin{array}{c}\text { Akilu et al. } \\
\text { [57] }\end{array}$ \\
\hline $\begin{array}{c}\mathrm{TiO}_{2}+\mathrm{SiO}_{2} \text { in } \\
\mathrm{W} / \mathrm{EG}(0.5-3.0 \\
\text { vol. } \%)\end{array}$ & $\begin{array}{c}\text { Rotational spindle / } \\
\text { Brookfield } \\
\text { Rheometer } \\
\left(30-80{ }^{\circ} \mathrm{C}\right)\end{array}$ & $\begin{array}{l}\text { Viscosity increased with increasing } \\
\text { concentration but decreased with } \\
\text { increasing temperature. } \\
\text { Maximum enhancement }(62.5 \%) \text { at } \phi= \\
\text { 3.0\%. Classification: Newtonian. }\end{array}$ & $\begin{array}{c}\text { Nabil et al. } \\
{[30]}\end{array}$ \\
\hline $\begin{array}{c}\mathrm{Fe}_{3} \mathrm{O}_{4}+\mathrm{CNT} \\
\mathrm{Fe}_{3} \mathrm{O}_{4}(0.1-0.9 \\
\text { vol. } \%) \\
\mathrm{CNT}(0-1.35 \\
\text { vol. } \%)\end{array}$ & $\begin{array}{c}\text { Rotation / Physica } \\
\text { MCR300 } \\
\left(25-55^{\circ} \mathrm{C}\right)\end{array}$ & $\begin{array}{l}\text { Viscosity increased with the increasing } \phi \\
\text { of } \mathrm{CNT} \text { or } \mathrm{Fe}_{3} \mathrm{O}_{4} \text { and decreasing with the } \\
\text { increasing of temperature. } \\
\text { Viscosity decreased with the increment } \\
\text { in shear rate. Classification: non- } \\
\text { Newtonian. }\end{array}$ & $\begin{array}{l}\text { Shahsavar } \\
\text { and } \\
\text { Bahiraei } \\
\text { [58] }\end{array}$ \\
\hline
\end{tabular}

\section{Density and specific heat}

The evaluation of any thermal systems with utilization of nanofluids requires precise particulars on thermo-physical properties. However, the research work for the investigation on the density and specific heat of nanofluids is limited in the printed matter and digital sources when compared to the evaluation on thermal conductivity and dynamic viscosity. Hence, only few important studies are presented in this section.

Density can be defined as a quantity of the mass of a substance per unit volume. Adding nanoparticles into the base fluid would enhance the density of mixture since the density of solid is greater than the liquids. The density of nanofluids is also proportional to the volume ratio of the solid (nanoparticle) and liquid (base fluid) in the system [59]. The density of nanofluids can be estimated by using conventional mixture relations. The equations are given by Eqs. (1) and (2) and used for the estimation of single nanofluids and hybrid nanofluids, respectively. Both equations were used by various studies in the literature [60-63]. 
The density mixture relation for single nanofluids is given by Equation (1).

$$
\rho_{n f}=\varphi \rho_{p}+(1-\varphi) \rho_{b f}
$$

The density mixture relation for hybrid nanofluids is expressed by Equation (2). The subscripts of $b f, n f, h n f, p_{1}$ and $p_{2}$ represent base fluid, nanofluids, hybrid nanofluids, nanoparticle type 1 and nanoparticle type 2 , respectively.

$$
\rho_{\text {hnf }}=(\varphi \rho)_{p_{1}}+(\varphi \rho)_{p_{2}}+(1-\varphi) \rho_{b f}
$$

Sommers and Yerkes [60] measured the density of $\mathrm{Al}_{2} \mathrm{O}_{3} /$ propanol nanofluids by using two methods. They used hydrometer in the first method. Meanwhile, in the second method, they evaluated the density using simple calculations from the conventional density equation by measuring volume and weight of the fluid sample. The data undertaken from both methods were compared with the estimated density by using the mixing theory from Eq. (1). They observed a small difference with less than 5\% deviation for measurements up to $5 \%$ weight concentration. Later, Ho et al. [61] investigated the density of $\mathrm{Al}_{2} \mathrm{O}_{3} /$ water nanofluids for a wide range of concentration and temperature of 0 to $4 \%$ and 10 to $40{ }^{\circ} \mathrm{C}$, respectively. From their measurements, the density of the nanofluids agreed well with the estimated values from the mixing theory. Similarly, Heyhat et al. [62] observed that the density measurement for $\mathrm{Al}_{2} \mathrm{O}_{3} /$ water nanofluids with 0.1 to $2.0 \%$ volume concentration and 20 to $60{ }^{\circ} \mathrm{C}$ temperature were found to be in good agreement with the mixing theory. In another paper, Nabati Shoghl et al. [63] reported the density of five types of water based nanofluids namely $\mathrm{Al}_{2} \mathrm{O}_{3} /$ water, $\mathrm{CuO} /$ water, $\mathrm{MgO}$ /water, $\mathrm{TiO}_{2} /$ water and $\mathrm{ZnO} /$ water for mass concentrations of 0.01 to $2.0 \%$. The density of different nanofluids was compared with the estimation density by using the mixture relation. The findings showed that the density can be predicted by the mixture relation. The nanofluids density increased with increasing concentration however decreased when temperature increased. A mixture of heat capacities of solid and liquid phases when the phases are in thermal equilibrium is known as nanofluid specific heat [64]. The specific heat of nanofluids is smaller than the base fluid. This implies that the heat energy required is lesser for nanofluids at the same temperature increment compared to the base fluids [59]. The specific heat is estimated using thermal equilibrium condition as given in Equation (3) for single nanofluids. The specific heat of nanofluids requires the constituent's material densities, specific heat and volume concentration. The specific heat of hybrid nanofluids was derived from Equation (3). It consists of two types of nanoparticles and presented by Equation (4). Equations (3) and (4) were used in various studies [44, 65-68]. However, some researchers developed specific heat empirical model for their respective nanoparticle types, sizes, concentrations and temperatures [69-71]. The specific heat of single nanofluids is expressed by Equation (3).

$$
C_{n f}=\frac{(1-\varphi)(\rho C)_{b f}+\varphi(\rho C)_{p}}{(1-\varphi) \rho_{b f}+\varphi \rho_{p}}
$$

The specific heat of hybrid nanofluids is given by Equation (4). The subscript of $b f$, $n f, h n f, p_{1}$ and $p_{2}$ represent base fluid, nanofluids, hybrid nanofluids, nanoparticle type 1 and nanoparticle type 2 , respectively.

$$
C_{h n f}=\frac{(1-\varphi)(\rho C)_{b f}+(\varphi \rho C)_{p_{1}}+(\varphi \rho C)_{p_{2}}}{\rho_{h n f}}
$$

Zhou and $\mathrm{Ni}$ [65] measured the specific heat of $\mathrm{Al}_{2} \mathrm{O}_{3} /$ water nanofluids at concentrations of 0 to $21.7 \%$ by using differential scanning calorimeter. The results indicated 
that the specific heat of the nanofluids decreased gradually with increasing nanoparticle concentration. Their results also showed a good agreement with the prediction from the thermal equilibrium model of Eq. (3). O'Hanley et al. [66] studied the specific heat for $\mathrm{Al}_{2} \mathrm{O}_{3} /$ water, $\mathrm{CuO} /$ water and $\mathrm{SiO}_{2}$ /water nanofluids. They reported that the specific heat increased with temperature but decreased with concentration. Their results were found to be in excellent agreement with the thermal equilibrium model. Barbés et al. [67] conducted a study on specific heat of $\mathrm{Al}_{2} \mathrm{O}_{3} /$ water and $\mathrm{Al}_{2} \mathrm{O}_{3} / \mathrm{EG}$ nanofluids at temperatures of 25 to 65 ${ }^{\circ} \mathrm{C}$ using a micro calorimeter. The results for both nanofluids were reported to be in agreement with the observation undertaken by Zhou and Ni [65]. The specific heat decreased with increasing concentration. Similarly, the measured specific heat was compared with the prediction by using the thermal equilibrium model and found to be in good agreement. On the other hand, Equation (4) was used by Madhesh et al. [44] and Nuim Labib et al. [68] to estimate the specific heat of their $\mathrm{Cu}+\mathrm{TiO}_{2}$ /water and $\mathrm{Al}_{2} \mathrm{O}_{3}+\mathrm{CNT} /$ water hybrid nanofluids, respectively. Table 3 summarized the measurement for density and specific heat of oxide nanofluids. 
Table 3. Summary of density and specific heat measurements for oxide nanofluids.

\begin{tabular}{|c|c|c|c|}
\hline $\begin{array}{l}\text { Nanofluids } \\
\text { (Range of } \\
\text { concentration) }\end{array}$ & $\begin{array}{l}\text { Measurement } \\
\text { method / } \\
\text { Instrument } \\
\text { (Temperature) }\end{array}$ & Significance findings & References \\
\hline \multicolumn{4}{|c|}{ Density } \\
\hline $\begin{array}{c}\mathrm{Al}_{2} \mathrm{O}_{3} \text { in } \\
\text { propanol } \\
\text { (up to } 5 \mathrm{wt} . \% \text { ) }\end{array}$ & $\begin{array}{l}\text { i. Hydrometer } \\
\text { ii. Measured } \\
\text { mass/volume } \\
\text { (Room } \\
\text { temperature) }\end{array}$ & $\begin{array}{l}\text { A difference of less than } 5 \% \text { was observed } \\
\text { for concentration up to } 5 \mathrm{wt} . \% \text {, compared to } \\
\text { mixing theory relation. }\end{array}$ & $\begin{array}{l}\text { Sommers } \\
\text { and Yerkes } \\
{[60]}\end{array}$ \\
\hline $\begin{array}{l}\mathrm{Al}_{2} \mathrm{O}_{3} \text { in water } \\
(0-4.0 \text { vol. } \%) \\
\end{array}$ & $\begin{array}{l}\text { Density meter } \\
\left(10-40^{\circ} \mathrm{C}\right)\end{array}$ & $\begin{array}{l}\text { The measured density in good agreement } \\
\text { with mixing theory relation. }\end{array}$ & $\begin{array}{l}\text { Ho et al. } \\
{[61]}\end{array}$ \\
\hline $\begin{array}{l}\mathrm{Al}_{2} \mathrm{O}_{3} \text { in water } \\
(0.1-2.0 \text { vol. } \%)\end{array}$ & $\begin{array}{c}\text { Stabinger } \\
\text { Viscometer } \\
\left(20-60{ }^{\circ} \mathrm{C}\right)\end{array}$ & $\begin{array}{l}\text { The measured density in good agreement } \\
\text { with mixing theory relation. }\end{array}$ & $\begin{array}{l}\text { Heyhat et } \\
\text { al. [62] }\end{array}$ \\
\hline $\begin{array}{c}\mathrm{Al}_{2} \mathrm{O}_{3}, \mathrm{CuO}, \\
\mathrm{MgO}, \mathrm{TiO}_{2} \\
\mathrm{ZnO} \text { in water } \\
(0.01-2.0 \text { wt. } \%)\end{array}$ & $\begin{array}{l}\text { Density meter } \\
\left(30 \text { and } 40^{\circ} \mathrm{C}\right)\end{array}$ & $\begin{array}{l}\text { Density can be predicted by the mixture } \\
\text { theory relation. The nanofluids density were } \\
\text { also increased with increasing of } \\
\text { concentration and decreased with increasing } \\
\text { of temperature. }\end{array}$ & $\begin{array}{l}\text { Nabati } \\
\text { Shoghl et } \\
\text { al. [63] }\end{array}$ \\
\hline \multicolumn{4}{|c|}{ Specific heat } \\
\hline $\begin{array}{l}\mathrm{Al}_{2} \mathrm{O}_{3} \text { in water } \\
(0-21.7 \text { vol. } \%)\end{array}$ & $\begin{array}{l}\text { Differential } \\
\text { scanning } \\
\text { calorimeter } \\
\left(25-40^{\circ} \mathrm{C}\right)\end{array}$ & $\begin{array}{l}\text { Specific heat declines gradually as the } \\
\text { nanoparticle concentration increases. }\end{array}$ & $\begin{array}{l}\text { Zhou and } \\
\text { Ni [65] }\end{array}$ \\
\hline $\begin{array}{l}\mathrm{Al}_{2} \mathrm{O}_{3}, \mathrm{CuO} \\
\mathrm{SiO}_{2} \text { in water } \\
(5-50 \text { wt. } \%)\end{array}$ & $\begin{array}{c}\text { Differential } \\
\text { scanning } \\
\text { calorimeter }(35,45, \\
\left.55^{\circ} \mathrm{C}\right)\end{array}$ & $\begin{array}{l}\text { Specific heat increased with temperature but } \\
\text { decreased with concentration. }\end{array}$ & $\begin{array}{l}\text { O'Hanley et } \\
\text { al. [66] }\end{array}$ \\
\hline $\begin{array}{l}\mathrm{Al}_{2} \mathrm{O}_{3} \text { in water } \\
(3.7-9.3 \text { vol. } \%) \\
/ \mathrm{Al}_{2} \mathrm{O}_{3} \text { in } \mathrm{EG} \\
(1.0-8.0 \text { vol. } \%)\end{array}$ & $\begin{array}{l}\text { Microcalorimeter } \\
\qquad\left(25-65^{\circ} \mathrm{C}\right)\end{array}$ & $\begin{array}{l}\text { Specific heat decreased with increasing of } \\
\text { concentration. }\end{array}$ & $\begin{array}{l}\text { Barbés et } \\
\text { al. [67] }\end{array}$ \\
\hline $\begin{array}{c}\mathrm{Al}_{2} \mathrm{O}_{3}, \mathrm{CuO} \\
\mathrm{SiO}_{2}, \mathrm{TiO}_{2} \\
(0.01-4.0 \\
\text { vol. } \%)\end{array}$ & $\begin{array}{l}20<T<50{ }^{\circ} \mathrm{C} \\
15<d_{p}<50 \mathrm{~nm}\end{array}$ & $C_{p_{r}}=0.8429\left(1+\frac{T_{n f}}{50}\right)^{-0.3037}\left(1+\frac{d_{p}}{50}\right)^{0.4167}\left(1+\frac{\phi}{100}\right)^{2.272}$ & $\begin{array}{l}\text { Sekhar and } \\
\text { Sharma } \\
\text { [69] }\end{array}$ \\
\hline
\end{tabular}

In thermo-physical properties evaluation, the nanofluids were proven to show better thermal properties and high enhancements in thermal conductivity with acceptable viscosity increments. The properties of the oxide nanofluids were measured for temperatures ranging from 10 to $90{ }^{\circ} \mathrm{C}$. Most studies in literature used transient hot wire methods to measure 
thermal conductivity and rotational spindle for viscosity measurements of oxide nanofluids. The oxide nanofluids and its hybrid were observed to display Newtonian behaviour at volume concentrations of less than $8.0 \%$ for single nanofluids and up to $2.0 \%$ volume concentration for hybrid nanofluids. The evaluation of thermal conductivity and dynamic viscosity mostly were determined through experimental measurements. The mixture relations for single and hybrid nanofluids were used by various researchers to estimate specific heat and density of nanofluids. The equations were used in the analysis of the present study to estimate the specific heat and density of the hybrid nanofluids. Figure 1 shows the variation of thermal conductivity enhancement for several type of metal oxide nanofluids. Maximum $40 \%$ enhancement of the thermal conductivity of oxide nanofluids was achieved for the case of $\mathrm{CuO} /$ water nanofluids in comparison with base fluids [35].

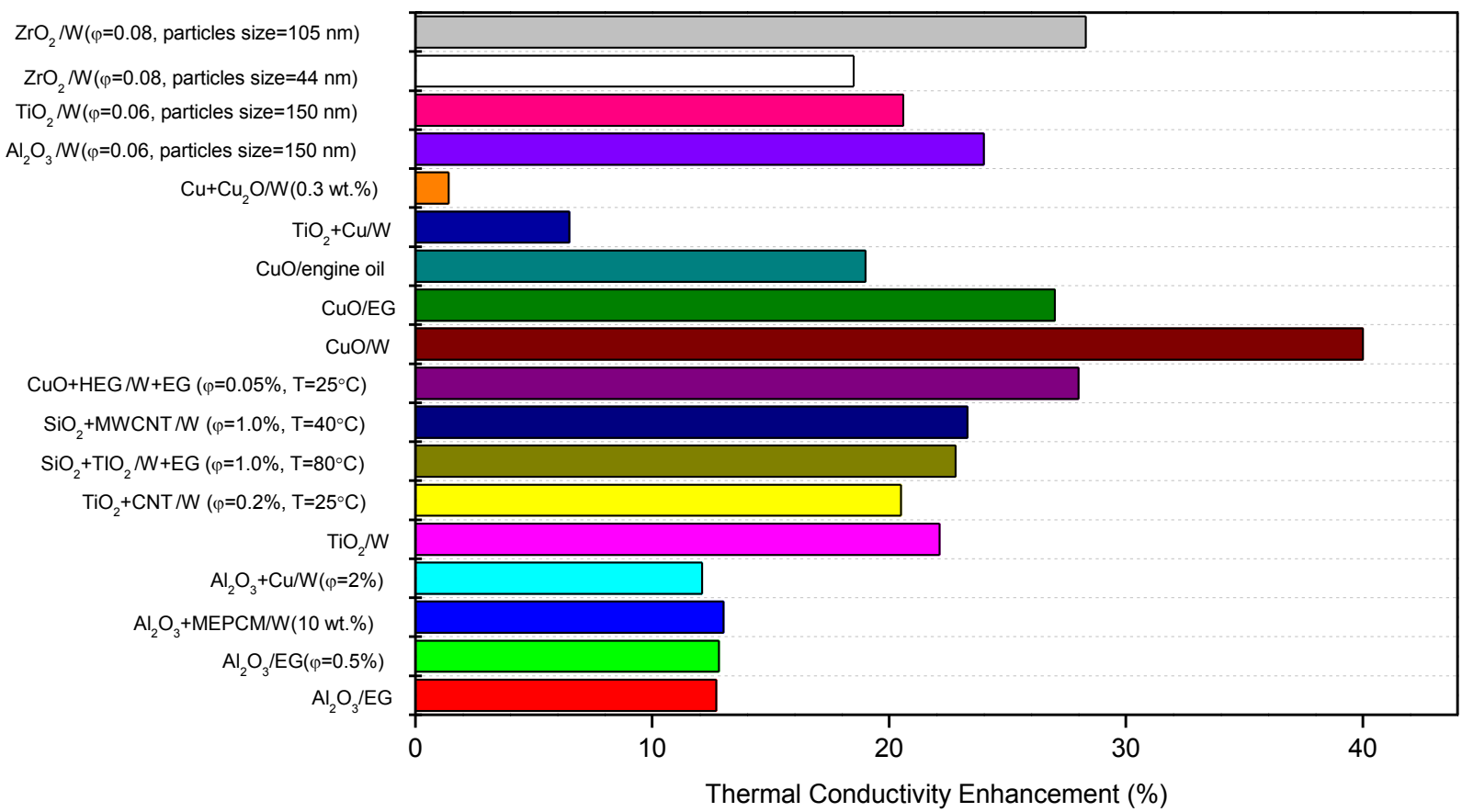

Figure 1. The variation of thermal conductivity enhancement for different type of metal oxide nanofluids. 


\section{HEAT TRANSFER PERFORMANCE OF OXIDE NANOFLUIDS}

The nanofluids were proven to enhance thermal properties by different studies and summarized in the previous section. Furthermore, various studies were undertaken either through experiment or numerically in order to investigate the heat transfer performance of oxide nanofluids. Forced convection heat transfer is one of the common methods to investigate the nanofluid behaviour on the heat transfer performance. The heat transfer enhancement can be achieved by increasing either the surface area where heat transfer occurred or the heat transfer coefficient between fluid and solid surface. At this condition, it will allow a high rate of heat transfer in small volumes [72]. The nanofluids are believed to have potential as a cooling agent or heat transfer fluids. The fundamental forced convection heat transfer observation of nanofluids is important as a benchmark for various diverse industries cooling applications such as manufacturing, solid-state lighting, power generation, micro-manufacturing, transportation, chemical and metallurgical sectors, thermal therapy for cancer treatment, ventilation, heating, cooling and air-conditioning as well as renewable energy. The following section describes numerous important studies of heat transfer for different types of oxide nanofluids and summarized in Table 4. The reviews considered the investigation of oxide nanofluids by experimental or numerical works with some important parameters namely, flow region, nanofluid properties, conditions, geometric designs and inserts in which significantly affected the overall heat transfer performance. Figure 2 presents the variation of heat transfer performance for various types of metal oxide nanofluids in a plain tube. In the literature, the heat transfer performance was improved for up to $60 \%$ with the use of $\mathrm{Fe}_{3} \mathrm{O}_{4} /$ water nanofluids in the heat transfer system under laminar flow condition [73]. 
Table 4. Summary of forced convection heat transfer with different test section for oxide nanofluids.

\begin{tabular}{|c|c|c|c|}
\hline $\begin{array}{c}\text { Nanofluids } \\
\text { (Range of } \\
\text { concentration) }\end{array}$ & $\begin{array}{l}\text { Types of study / } \\
\text { Test section / } \\
\text { Range of Re }\end{array}$ & $\begin{array}{l}\text { Enhancement in } N u, h, f / \\
\text { Significant findings }\end{array}$ & References \\
\hline $\begin{array}{l}\mathrm{Al}_{2} \mathrm{O}_{3} \text { in water } \\
(0-2.5 \text { vol. } \%)\end{array}$ & $\begin{array}{l}\text { Experiment / Plain } \\
\text { tube with butterfly } \\
\text { tube inserts / } \\
\operatorname{Re}(750-8,500)\end{array}$ & $\begin{array}{l}\text { Enhancement in } N u(345 \%) \text { at } \phi= \\
0.027 \% \text { and } R e=1,500 \text { with insert. } \\
\text { Further enhancement in } N u \text { at } \phi= \\
2.5 \% \text { with insert } \\
\text { Increment in } f(2.6 \%)\end{array}$ & $\begin{array}{c}\text { Azari and } \\
\text { Derakhshandeh } \\
\text { [74] }\end{array}$ \\
\hline $\begin{array}{l}\mathrm{Al}_{2} \mathrm{O}_{3} \text { in water } \\
(0-6.0 \text { vol. } \%)\end{array}$ & $\begin{array}{l}\text { Numerical / Circular } \\
\text { tube / } \operatorname{Re}(5,000- \\
18,000)\end{array}$ & $\begin{array}{l}\text { Optimal cross section area increased } \\
\text { as increasing the } R e\end{array}$ & $\begin{array}{l}\text { Mwesigye and } \\
\text { Huan [75] }\end{array}$ \\
\hline $\begin{array}{l}\mathrm{Al}_{2} \mathrm{O}_{3} \text { in water } \\
(0-4.0 \text { vol. } \%)\end{array}$ & $\begin{array}{l}\text { Numerical / Mini- } \\
\text { channel with ribbed } \\
\text { upper and lower } \\
\text { walls (triangular, } \\
\text { rectangular and } \\
\text { trapezoidal) / Re } \\
(20,000-60,000)\end{array}$ & $\begin{array}{l}\text { Heat transfer rate increased with } \\
\text { increasing of } \phi \text { and } R e \text { however with } \\
\text { additional pumping power. The } \\
\text { thermal performance of triangular rib } \\
\text { is higher than rectangular and } \\
\text { trapezoidal ribs. }\end{array}$ & $\begin{array}{l}\text { Andreozzi et } \\
\text { al. [76] }\end{array}$ \\
\hline $\begin{array}{l}\mathrm{Al}_{2} \mathrm{O}_{3} \text { in water } \\
(0-0.1 \text { vol. } \%)\end{array}$ & $\begin{array}{l}\text { Numerical / Mini- } \\
\text { channel }\end{array}$ & $\begin{array}{l}\text { Compared to the shear-induced } \\
\text { diffusion and viscosity gradient- } \\
\text { induced diffusion, Brownian } \\
\text { diffusion and thermophoresis are } \\
\text { considered more significant } \\
\text { mechanisms based on their impacts } \\
\text { on volume fraction distribution of } \\
\text { nanofluids. }\end{array}$ & $\begin{array}{l}\text { Yang et al. } \\
\text { [77] }\end{array}$ \\
\hline $\begin{array}{l}\mathrm{Al}_{2} \mathrm{O}_{3} \text { in water } \\
(2-10 \text { wt. } \%)\end{array}$ & $\begin{array}{l}\text { Experiment / } \\
\text { Circular tube / Re } \\
(188-2,095)\end{array}$ & $\begin{array}{l}\text { Heat transfer effectiveness increases } \\
\text { with the decreasing of parameter } l *_{h} \text {. } \\
\text { Higher average heat transfer } \\
\text { effectiveness and figure of merit } \\
(\text { FOM) are noted for cases with } \\
\text { higher inlet fluid temperature }(45.5 \text { - } \\
\left.50.5^{\circ} \mathrm{C}\right) \text {. }\end{array}$ & Ho et al. [78] \\
\hline $\begin{array}{c}\mathrm{Al}_{2} \mathrm{O}_{3} \text { in } \\
\text { water/EG }(0.2- \\
1.0 \text { vol. } \%)\end{array}$ & $\begin{array}{l}\text { Experiment / } \\
\text { Circular tube / Re } \\
(3,000-25,000)\end{array}$ & $\begin{array}{l}\text { Enhancement in } N u(24.6 \%) \text { for the } \\
\text { base ratio W/EG }(60: 40), \phi=1.0 \% \\
\text { and } 70{ }^{\circ} \mathrm{C} \text {. Increment of } f \text { is slightly } \\
\text { increased with increment of } \phi \text {. }\end{array}$ & $\begin{array}{l}\text { Azmi et al. } \\
\text { [79] }\end{array}$ \\
\hline $\begin{array}{c}\mathrm{TiO}_{2} \text { in } \\
\text { water/EG }(0.5- \\
1.5 \text { vol. } \%)\end{array}$ & $\begin{array}{l}\text { Experiment / } \\
\text { Circular tube / Re } \\
(3,000-22,000)\end{array}$ & $\begin{array}{l}\text { Enhancement in } \mathrm{Nu}(22.8 \% \text { and } \\
28.9 \% \text { at } 50{ }^{\circ} \mathrm{C} \text { and } 70{ }^{\circ} \mathrm{C} \text {, } \\
\text { respectively) and significantly for }\end{array}$ & $\begin{array}{l}\text { Khdher et al. } \\
\qquad[80]\end{array}$ \\
\hline
\end{tabular}




\begin{tabular}{|c|c|c|c|}
\hline & & $\begin{array}{l}\text { higher } \phi . \text { Increment in } f(1.1 \text { times the } \\
\text { base fluid). }\end{array}$ & \\
\hline $\begin{array}{l}\mathrm{TiO}_{2} \text { in water } \\
(0.1-0.5 \text { vol. } \%)\end{array}$ & $\begin{array}{l}\text { Experimental \& } \\
\text { numerical / } \\
\text { Helical coil pipe ( } 5 \\
\text { curvature ratio) / Re } \\
(3,000-18,000)\end{array}$ & $\begin{array}{l}\text { Enhancement in } N u(30 \%) \text { at } \phi= \\
0.5 \%, h \text { increased when the Dean } \\
\text { number (curvature ratio) is increasing } \\
\text { at fixed } R e \text {. Increment in } f \text { (higher } f \\
\text { with helical coil when compared to } \\
\text { base fluid) }\end{array}$ & $\begin{array}{l}\text { Mahmoudi et } \\
\text { al. [81] }\end{array}$ \\
\hline $\begin{array}{l}\mathrm{TiO}_{2} \text { in water } \\
(0.1-0.5 \text { wt. } \%)\end{array}$ & $\begin{array}{l}\text { Experimental \& } \\
\text { numerical / } \\
\text { Corrugated tube / } \\
\operatorname{Re}(<12,000)\end{array}$ & $\begin{array}{l}\text { Enhancement in } h(53.95 \% \text { and } \\
16.06 \% \text { for corrugated tube and } \\
\text { circular tube). Maximum } \\
\text { performance index (1.507) }\end{array}$ & Qi et al. [82] \\
\hline $\begin{array}{l}\mathrm{SiO}_{2} \text { and } \mathrm{TiO}_{2} \\
\text { in water } \\
(0.5-3.0 \text { vol. } \%)\end{array}$ & $\begin{array}{l}\text { Experiment / } \\
\text { Circular tube / } R e \\
(5,000-25,000)\end{array}$ & $\begin{array}{l}\text { Enhancement in } h(26 \%) \text { for } \\
\mathrm{TiO}_{2} / \text { water at } \phi=1.0 \% \text { and }(33 \%) \text { for } \\
\mathrm{SiO}_{2} / \text { water at } \phi=3.0 \%\end{array}$ & $\begin{array}{l}\text { Azmi et al. } \\
\quad[83]\end{array}$ \\
\hline $\begin{array}{c}\mathrm{CuO} \text { in oil } \\
(0.5-1.5 \mathrm{wt} \%)\end{array}$ & $\begin{array}{l}\text { Experiment / } \\
\text { Circular \& microfin } \\
\text { tube / } \operatorname{Re}(110-730)\end{array}$ & $\begin{array}{l}\text { Enhancement in } h(16 \% \text { and } 22 \% \text { for } \\
\text { circular tube and microfin tube, } \\
\text { respectively). Performance index } \\
\text { (1.16) for circular tube at } \phi=1.5 \% \text {, } \\
\text { (1.44) for microfin tube at } \phi=1.5 \%\end{array}$ & $\begin{array}{l}\text { Hekmatipour } \\
\text { et al. [84] }\end{array}$ \\
\hline $\begin{array}{l}\mathrm{CuO} \text { in water } \\
(0-4.0 \text { vol.\%) } \\
\text { (shape: } \\
\text { spherical, } \\
\text { platelet, } \\
\text { cylinder and } \\
\text { brick) }\end{array}$ & $\begin{array}{l}\text { Numerical / Semi } \\
\text { annulus / Re }(100- \\
600) \\
\text { Darcy number } \\
(0.01-100) \\
\text { Hartmann number } \\
(0-50)\end{array}$ & $\begin{array}{l}N u \text { enhanced with increasing of } \phi, R e \\
\text { and Darcy number. The platelet shape } \\
\text { has the greatest heat transfer rate } \\
\text { among other shape. }\end{array}$ & $\begin{array}{l}\text { Sheikholeslami } \\
\text { and Bhatti [85] }\end{array}$ \\
\hline $\begin{array}{l}\text { GO in water } \\
(0-0.2 \text { vol. } \%)\end{array}$ & $\begin{array}{l}\text { Experiment / Tube } \\
\text { in subsonic wind } \\
\text { tunnel / } \\
\operatorname{Re}(3,800-21,500)\end{array}$ & $\begin{array}{l}\text { Enhancement in } N u \quad(51.4 \%) \\
\text { compared to pure water. Increment in } \\
f(21 \%) \text {. Enhancement in } h(42.2 \%) \text {. }\end{array}$ & $\begin{array}{l}\text { Ranjbarzadeh } \\
\text { et al. [86] }\end{array}$ \\
\hline $\begin{array}{l}\mathrm{ZrO}_{2} \text { in water } \\
(4.0 \text { vol. } \%)\end{array}$ & $\begin{array}{l}\text { Experiment / Tubes } \\
\text { (smooth tube, } \\
\text { tube+annular } \\
\text { knurling, } \\
\text { tube+spherical } \\
\text { protrusions) / Re } \\
(3,000-8,000)\end{array}$ & $\begin{array}{l}\text { Enhancement in } h(+35 \%) \text { for size of } \\
44 \mathrm{~nm},(-20 \%) \text { for size of } 105 \mathrm{~nm} \text {. } \\
\text { Tube with annular knurling and } \\
\text { protrusions showed lower thermal } \\
\text { hydraulic efficiency compared to } \\
\text { smooth tube. }\end{array}$ & $\begin{array}{c}\text { Minakov et al. } \\
{[88]}\end{array}$ \\
\hline $\begin{array}{l}\mathrm{Fe}_{3} \mathrm{O}_{4} \text { in water } \\
\quad(4.0 \text { vol. } \%)\end{array}$ & $\begin{array}{l}\text { Numerical / Re }(10- \\
600) \text {, } \\
\text { Hartmann } \\
\text { number }(0-10) \text {, }\end{array}$ & $\begin{array}{l}\mathrm{Nu} \text { is increasing with } \operatorname{Re}, \phi \text { and } \\
\text { magnetic number. However, the } N u \text { is } \\
\text { decreasing with the Hartmann } \\
\text { number. }\end{array}$ & $\begin{array}{l}\text { Sheikholeslami } \\
\text { et al. [89] }\end{array}$ \\
\hline
\end{tabular}




\begin{tabular}{|c|c|c|c|}
\hline & $\begin{array}{l}\text { Magnetic number } \\
(0-10)\end{array}$ & & \\
\hline $\begin{array}{l}\mathrm{Fe}_{3} \mathrm{O}_{4} \text { in water } \\
(0.1-1.0 \text { vol.\%) }\end{array}$ & $\begin{array}{l}\text { Experiment / Re } \\
(<400), \text { Hartmann } \\
\text { number } \\
\left(33.4 \times 10^{-4}-\right. \\
\left.136.6 \times 10^{-4}\right)\end{array}$ & $\begin{array}{l}\text { Enhancement in } h(+60 \%) \text { with } \\
\text { increasing } \phi \text { without external } \\
\text { magnetic field, }(-25 \%) \text { with } \\
\text { increasing } \phi \text { in the presence of } \\
\text { magnetic field. }\end{array}$ & $\begin{array}{c}\text { Hatami et al. } \\
\text { [73] }\end{array}$ \\
\hline
\end{tabular}

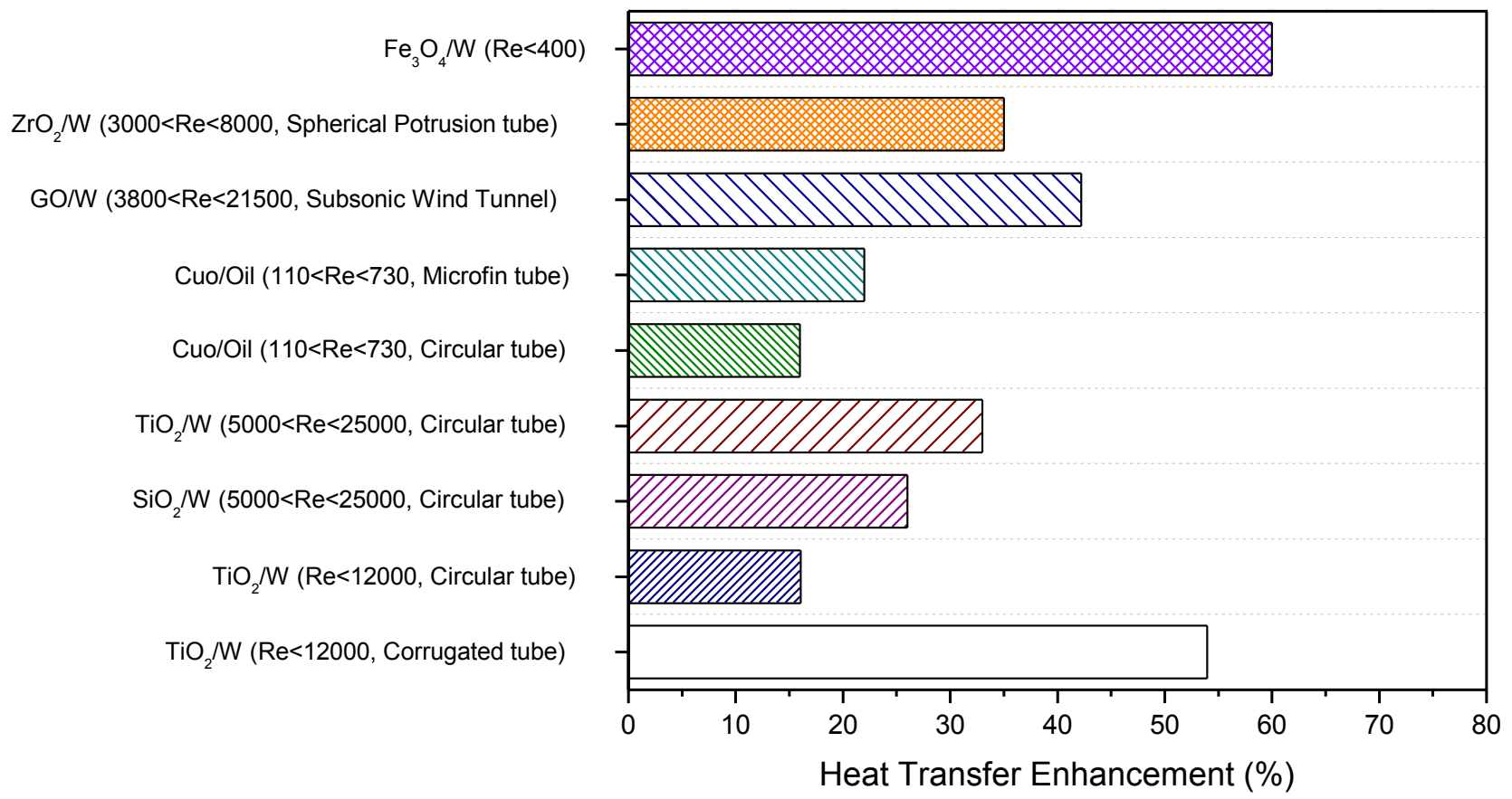

Figure 2. The variation of heat transfer augmentation for various types of metal oxide nanofluids in a plain tube.

\section{Aluminum Oxide Nanofluids}

Azari and Derakhshandeh [74] conducted a study with $\mathrm{Al}_{2} \mathrm{O}_{3} /$ water at concentrations of up to $2.5 \%$ and Reynolds number of 750 to 8,500 . The plain tube was equipped with butterfly tube inserts with inclined angle of $90^{\circ}$. They found that the nanofluid friction factor with inserts increased by an average of $2.6 \%$ relative to the plain tube. The Nusselt number enhancement was observed up to $345 \%$ for concentration of $0.027 \%$ and Reynolds number of 1,500 with insert when compared to the plain tube. Another $2.5 \%$ increment was obtained for Nusselt number with butterfly tube insert. Furthermore, Mwesigye and Huan [75] conducted a numerical study on thermodynamics analysis for turbulent forced convection in a circular tube with $\mathrm{Al}_{2} \mathrm{O}_{3}$ /water nanofluids. The study was conducted for different crosssectional areas, concentrations and Reynolds number at a wide range of $2.5 \times 10^{-6}$ to 0.05 $\mathrm{m}^{2}, 0$ to $6.0 \%$ and 5,000 to 18,000 , respectively. The results showed that the optimal crosssectional area increased with increasing Reynolds number. 
Andreozzi et al. [76] studied the numerical investigation on forced convection in mini-channel using $\mathrm{Al}_{2} \mathrm{O}_{3}$ /water nanofluids. The channel was designed with ribbed upper and lower walls. The experiment was conducted for 0 to $4 \%$ volume concentrations of nanofluids, Reynolds number ranges from 20,000 to 60,000 and heated under a constant heat flux condition. The effects of three rib geometries arrangement namely triangular, rectangular and trapezoidal were also investigated in their study. The results indicated the dependence of heat transfer rate on nanofluid concentrations and Reynolds number where it increases when the previously mentioned variables increase; however, there is a drawback with high pumping power requirements. The best thermal performance was observed with triangular rib compared to rectangular and trapezoidal ribs. In another paper, Yang et al. [77] studied forced convection in mini-channels with $\mathrm{Al}_{2} \mathrm{O}_{3}$ /water nanofluids. The numerical study was conducted for nanofluid concentrations of less than $0.1 \%$ using Runge-Kutta-Gill method. The results were analyzed by investigating the effect of different mechanisms on volume fraction distribution of nanofluids. Their findings showed that the Brownian diffusion and thermophoresis were reported as more dominant mechanisms than shear-induced diffusion and viscosity gradient-induced diffusion.

Ho et al. [78] conducted an experimental study on forced convection effectiveness of $\mathrm{Al}_{2} \mathrm{O}_{3} /$ water nanofluids in a circular tube. The study used $\mathrm{Al}_{2} \mathrm{O}_{3} /$ water nanofluids with 2 to $10 \%$ weight concentrations, Reynolds number of 188 to 2,095 and inlet temperature of 24.5 to $50.5^{\circ} \mathrm{C}$. Based on the results, they observed that the average heat transfer effectiveness increased with decreasing parameter $l * h$. In addition, the improvement in average heat transfer effectiveness and figure of merit (FOM) were recorded for cases with high inlet fluid temperature from 45.5 to $50.5{ }^{\circ} \mathrm{C}$. In another paper, Azmi et al. [79] conducted an experimental investigation of forced convection with $\mathrm{Al}_{2} \mathrm{O}_{3}$ nanoparticles for 0.2 to $1.0 \%$ volume concentration and three different ratios of water to EG mixture namely 60:40, 50:50 and 40:60. The experiment took place at different working temperatures of 30 to $70{ }^{\circ} \mathrm{C}$ and turbulent Reynolds number from 3,000 to 25,000. The results indicated that the $\mathrm{Al}_{2} \mathrm{O}_{3}$ nanofluids with 60:40 (W/EG) based ratio provided the highest heat transfer enhancement up to $24.6 \%$ for $1.0 \%$ volume concentration and $70{ }^{\circ} \mathrm{C}$ working temperature. A slight increase in friction factor was observed with increasing volume concentration.

\section{Titanium Dioxide Nanofluids}

Khdher et al. [80] carried out an experimental study of forced convection heat transfer for $\mathrm{TiO}_{2}$ nanoparticles in W/EG mixture. The nanofluids was tested in a circular tube for volume concentrations of 0.5 to $1.5 \%$ and different working temperatures of 50 and $70{ }^{\circ} \mathrm{C}$. The results showed that the enhancements of Nusselt number were reported up to $22.8 \%$ and $28.9 \%$ for temperatures of 50 and $70{ }^{\circ} \mathrm{C}$, respectively. The friction factor increased approximately 1.1 times higher than the base fluid. Another experimental and numerical study was undertaken by Mahmoudi et al. [81] for $\mathrm{TiO}_{2} /$ water nanofluids at volume concentrations of 0.1 to $0.5 \%$. The test section was equipped with helical coils and five curvature ratios. The results were obtained with $30 \%$ heat transfer enhancements for $0.5 \%$ volume concentration of nanofluids. The heat transfer increased with increasing Dean number (curvature ratio) at a constant Reynolds number. However, the use of a helical coil resulted in higher friction factors when compared to the base fluid. 
Later, Qi et al. [82] studied the heat transfer characteristics for corrugated tube by experimental and numerical investigations. The $\mathrm{TiO}_{2} /$ water nanofluids was tested with weight concentrations of 0.1 to $0.5 \%$ in circular and corrugated tubes for Reynolds number of less than 12,000. They reported that the maximum enhancement of heat transfer for corrugated tube and circular tube up to $53.95 \%$ and $16.06 \%$, respectively. In this case, the nanoparticle concentration in their study caused minimum additional resistance loss to the system. The maximum comprehensive performance index (ratio of Nusselt number to friction factor) was obtained up to 1.507. In another study, Azmi et al. [83] conducted a comparative experimental study for $\mathrm{SiO}_{2} /$ water and $\mathrm{TiO}_{2} /$ water nanofluids to investigate the convective heat transfer performance in a circular tube. The experiments were performed at turbulent Reynolds number of 5,000 to 25,000 and 0.5 to $3.0 \%$ volume concentrations for a constant working temperature of $30{ }^{\circ} \mathrm{C}$. According to the results, they reported $26 \%$ maximum enhancement of heat transfer coefficient for $\mathrm{TiO}_{2} /$ water nanofluids at $1.0 \%$ volume concentration. Meanwhile, heat transfer enhancement for $\mathrm{SiO}_{2} /$ water nanofluids was achieved up to $33 \%$ for $3.0 \%$ volume concentration.

\section{Copper (II) Oxide Nanofluids}

Hekmatipour et al. [84] conducted a study on convective heat transfer performance in a horizontal tube with $\mathrm{CuO}$ nanoparticles dispersed in heat transfer oil. The nanofluids were prepared for weight concentrations of 0.5 to $1.5 \%$. It was tested under the laminar flow with Reynolds number of 110 to 730 . The results reported an enhancement up to $16 \%$ of the heat transfer for circular tubes and $22 \%$ for microfin tubes by using $\mathrm{CuO} /$ oil nanofluids. In addition, the performance index was found to be more than unity for the majority of the results. The performance index for $1.5 \%$ weight concentration were obtained up to 1.16 and 1.44 for circular tube and microfin tube, respectively. Furthermore, Sheikholeslami and Bhatti [85] investigated a numerical study on forced convection of $\mathrm{CuO} /$ water nanofluids with the presence of uniform magnetic field. They tested the nanofluids with four different shapes of nanoparticles namely spherical, platelet, cylinder and brick. The experiment was undertaken for Reynolds number of 100 to 600, Darcy number of 0.01 to 100, Hartmann number of 0 to 50 and up to $4.0 \%$ concentration. The Nusselt number was enhanced with increasing nanoparticle concentrations, Reynolds number and Darcy number. Lastly, the platelet shape of nanoparticles recorded the highest heat transfer rate when compared to other shapes.

\section{Other types of Oxide Nanofluids}

Ranjbarzadeh et al. [86] examined the effects of graphene oxide/water nanofluids on convective heat transfer for a tube under air-cross flow. The experiment was performed for a wide range of Reynolds number from 3,800 to 21,500 and up to $0.2 \%$ volume concentration. The free air flow was generated by a subsonic wind tunnel. In their study, the average Nusselt number for nanofluids was enhanced up to $51.4 \%$ better than pure water. The friction factor increased with increasing nanofluid concentration with $21 \%$ maximum increment. This is due to the increase with the viscosity of graphene oxide/water nanofluids. The heat transfer performance also was increased up to $42.2 \%$. Similar observation also was found by Zainal Abidin et al. [87] and Abdullah et al. [3] however for different types of nanofluids. Furthermore, Minakov et al. [88] evaluated the heat transfer performance of $\mathrm{ZrO}_{2} /$ water nanofluids for $4.0 \%$ volume concentrations with different nanoparticle sizes of 44 and 105 
nm. The experiment was undertaken for Reynolds number of 3,000 to 8,000 and different types of tubes viz. smooth tube, tube with annular knurling and tube with spherical protrusions. Their findings showed that $\mathrm{ZrO}_{2}$ nanoparticles with $44 \mathrm{~nm}$ improved the heat transfer by $35 \%$ when compared to the base fluid. Conversely, the $\mathrm{ZrO}_{2}$ nanoparticles with $105 \mathrm{~nm}$ decreased the heat transfer performance by 20\%. Then, the tube with annular knurling and protrusions experienced lower thermal hydraulic efficiency when compared to smooth tubes. Hence, the use of $\mathrm{ZrO}_{2}$ /water nanofluids in channels with artificial enhancers appeared to be less effective in terms of thermal hydraulic efficiency.

Sheikholeslami et al. [89] conducted a numerical study on convective heat transfer under the influence of a magnetic field. They utilized $\mathrm{Fe}_{3} \mathrm{O}_{4} /$ water nanofluids with $4.0 \%$ volume concentration. The nanofluids were tested for a wide range of Reynolds number from 10 to 600 and up to 10 for the Hartmann number and magnetic number. The results showed that the Nusselt number improved with increasing Reynolds number, nanofluid concentrations and magnetic number. On the contrary, the Nusselt number decreased with increasing Hartmann number. In another study, Hatami et al. [73] investigated the heat transfer performance of $\mathrm{Fe}_{3} \mathrm{O}_{4}$ /water nanofluids under a magnetic field. The experiment was conducted for laminar flow with Reynolds number of less than 400, Hartmann number of $33.4 \times 10^{-4}$ to $136.6 \times 10^{-4}$ and nanofluid concentrations of 0.1 to $1.0 \%$. By increasing the volume concentration, this will cause a $25 \%$ reduction in convective heat transfer coefficient with the presence of a magnetic field. However, the increment of nanoparticle loading enhanced the heat transfer for more than $60 \%$ without the existence of an external magnetic field.

\section{CONCLUSIONS}

In the present paper, a comprehensive summary on thermo-physical properties and heat transfer application of oxide nanofluids was reviewed. The oxide nanofluids are widely used in numerous engineering applications. The oxide nanofluids is one of the favorable single type nanofluids being used in preparations of hybrid or composite nanofluids. $\mathrm{Al}_{2} \mathrm{O}_{3}, \mathrm{TiO}_{2}$, $\mathrm{SiO}_{2}$ and $\mathrm{CuO}$ nanofluids are mostly used in heat transfer application. Meanwhile other types such as $\mathrm{Fe}_{3} \mathrm{O}_{4}, \mathrm{ZnO}$ and $\mathrm{MgO}$ nanofluids are also implemented, however with only a small number of studies reported. In thermo-physical properties evaluation, the oxide nanofluids were proven to perform better thermal properties and high enhancements in thermal conductivity with acceptable viscosity increments. In the literature, the thermal conductivity of oxide nanofluids was enhanced up to $40 \%$ better than the base fluids. Furthermore, the forced convection studies using oxide nanoparticles for single and hybrid nanofluids showed significant improvements in heat transfer performance. It was reported in the literature with the heat transfer enhancement up to $60 \%$ with the use of oxide nanofluids in the heat transfer system. In addition, some studies stated that the drawback with friction factor and pressure drop by utilizing the nanofluids in heat transfer system is insignificant. On this basis, we conclude that nanofluids are recommended in heat transfer system. 


\section{ACKNOWLEDGEMENTS}

The authors are grateful to the Ministry of Education Malaysia and Universiti Malaysia Pahang (www.ump.edu.my) for financial supports given under FRGS/1/2018/TK10/UMP/02/10, RDU190146 and PGRS1903110. The authors also thank the research team from Automotive Engineering Centre (AEC), Centre of Excellence for Advanced Research in Fluid Flow (CARIFF) and Advanced Automotive Liquids Laboratory (AALL), who provided insight and expertise that greatly assisted in the present research work.

\section{REFERENCES}

[1] Masuda H, Ebata A, Teramae K, Hishinuma N. Alteration of thermal conductivity and viscosity of liquid by dispersing ultra fine particles. Netsu Bussei. 1993;4:227233.

[2] Choi SUS. Enhancing thermal conductivity of fluids with nanoparticles. In: Siginer DA, Wang HP, editors. Developments and Applications of Non-Newtonian Flows. New York: American Society of Mechanical Engineers (ASME); 1995. p. 99-105.

[3] Abdullah A, Mohamad IS, Bani Hashim AY, Abdullah N, Wei PB, Isa MHM, Zainal Abidin S. Thermal conductivity and viscosity of deionised water and ethylene glycolbased nanofluids. Journal of Mechanical Engineering and Sciences. 2016;10:22492261.

[4] Sahid NSM, Rahman MM, Kadirgama K, Maleque MA. Experimental investigation on properties of hybrid nanofluids $\left(\mathrm{TiO}_{2}\right.$ and $\left.\mathrm{ZnO}\right)$ in water-ethylene glycol mixture. Journal of Mechanical Engineering and Sciences. 2017;11:3087-3094.

[5] Sharma S, Tiwari AK, Tiwari S, Prakash R. Viscosity of hybrid nanofluids: Measurement and comparison. Journal of Mechanical Engineering and Sciences. 2018;12:3614-3623.

[6] Zakaria I, Azmi WH, Mohamed WANW, Mamat R, Najafi G. Experimental Investigation of thermal conductivity and electrical conductivity of $\mathrm{Al}_{2} \mathrm{O}_{3}$ nanofluid in water - ethylene glycol mixture for proton exchange membrane fuel cell application. International Communications in Heat and Mass Transfer. 2015;61:6168.

[7] Kottasamy A, Kadirgama K, Annamalai K, Mohanesan K, Ramasamy D, Noor MM, Rahman MM, Hanipah MR. Titanium oxide with nanocoolant for heat exchanger application. Journal of Mechanical Engineering and Sciences. 2017;11:2834-2844.

[8] Sangmesh B, Gopalakrishna K, Manjunath SH, Kathyayini N, Kadirgama K, Samykano M, Vijayakumar GC. Experimental investigation on HSFP using MWCNT based nanofluids for high power light emitting diodes. Journal of Mechanical Engineering and Sciences. 2018;12:3852-3865.

[9] Lee KJ, Yoon SH, Jang J. Carbon nanofibers: A novel nanofiller for nanofluid applications. Small. 2007;3:1209-1213.

[10] Babita, Sharma SK, Gupta SM. Preparation and evaluation of stable nanofluids for heat transfer application: A review. Experimental Thermal and Fluid Science. 2016;79:202-212. 
[11] Suganthi KS, Rajan KS. Metal oxide nanofluids: Review of formulation, thermophysical properties, mechanisms, and heat transfer performance. Renewable and Sustainable Energy Reviews. 2017;76:226-255.

[12] Manna I. Synthesis, characterization and application of nanofluid - An overview. Journal of the Indian Institute of Science. 2009;89:21-33.

[13] Azmi WH, Abdul Hamid K, Mamat R, Sharma KV, Mohamad MS. Effects of working temperature on thermo-physical properties and forced convection heat transfer of $\mathrm{TiO}_{2}$ nanofluids in water - Ethylene glycol mixture. Applied Thermal Engineering. 2016;106:1190-1199.

[14] Islam R, Shabani B, Andrews J, Rosengarten G. Experimental investigation of using $\mathrm{ZnO}$ nanofluids as coolants in a PEM fuel cell. International Journal of Hydrogen Energy. 2017;42:19272-19286.

[15] Hamid KA, Azmi WH, Nabil MF, Mamat R, Sharma KV. Experimental investigation of thermal conductivity and dynamic viscosity on nanoparticle mixture ratios of TiO2-SiO2 nanofluids. International Journal of Heat and Mass Transfer. 2018;116:1143-1152.

[16] Ranjbarzadeh R, Moradikazerouni A, Bakhtiari R, Asadi A, Afrand M. An experimental study on stability and thermal conductivity of water/silica nanofluid: Eco-friendly production of nanoparticles. Journal of Cleaner Production. 2019;206:1089-1100.

[17] Nabil MF, Azmi WH, Hamid KA, Mamat R. Experimental investigation of heat transfer and friction factor of $\mathrm{TiO}_{2}-\mathrm{SiO}_{2}$ nanofluids in water:ethylene glycol mixture. International Journal of Heat and Mass Transfer. 2018;124:1361-1369.

[18] Nabil MF, Azmi WH, Hamid KA, Zawawi NNM, Priyandoko G, Mamat R. Thermophysical properties of hybrid nanofluids and hybrid nanolubricants: A comprehensive review on performance. International Communications in Heat and Mass Transfer. 2017;83:30-39.

[19] Solangi KH, Kazi SN, Luhur MR, Badarudin A, Amiri A, Sadri R, Zubir MNM, Gharehkhani S, Teng KH. A comprehensive review of thermo-physical properties and convective heat transfer to nanofluids. Energy. 2015;89:1065-1086.

[20] Abdolbaqi MK, Azmi WH, Mamat R, Sharma KV, Najafi G. Experimental investigation of thermal conductivity and electrical conductivity of BioGlycol-water mixture based $\mathrm{Al}_{2} \mathrm{O}_{3}$ nanofluid. Applied Thermal Engineering. 2016;102:932-941.

[21] Chiam HW, Azmi WH, Usri NA, Mamat R, Adam NM. Thermal conductivity and viscosity of $\mathrm{Al}_{2} \mathrm{O}_{3}$ nanofluids for different based ratio of water and ethylene glycol mixture. Experimental Thermal and Fluid Science. 2017;81:420-429.

[22] Zawawi NNM, Azmi WH, Sharif MZ, Najafi G. Experimental investigation on stability and thermo-physical properties of $\mathrm{Al}_{2} \mathrm{O}_{3}-\mathrm{SiO}_{2} / \mathrm{PAG}$ nanolubricants with different nanoparticle ratios. Journal of Thermal Analysis and Calorimetry. 2019;135:1243-1255.

[23] Ramadhan AI, Azmi WH, Mamat R, Hamid KA, Norsakinah S. Investigation on stability of tri-hybrid nanofluids in water-ethylene glycol mixture. IOP Conference Series: Materials Science and Engineering. 1 ed2019. p. 012068.

[24] Sharif MZ, Azmi WH, Redhwan AAM, Mamat R. Investigation of thermal conductivity and viscosity of $\mathrm{Al}_{2} \mathrm{O}_{3} / \mathrm{PAG}$ nanolubricant for application in automotive air conditioning system. International Journal of Refrigeration. 2016;70:93-102. 
[25] Sundar LS, Sharma KV, Singh MK, Sousa ACM. Hybrid nanofluids preparation, thermal properties, heat transfer and friction factor - A review. Renewable and Sustainable Energy Reviews. 2017;68, Part 1:185-198.

[26] Hamid KA, Azmi WH, Mamat R, Usri NA, Najafi G. Effect of temperature on heat transfer coefficient of titanium dioxide in ethylene glycol-based nanofluid. Journal of Mechanical Engineering and Sciences. 2015;8:1367-1375.

[27] Hamid KA, Azmi WH, Mamat R, Sharma KV. Experimental investigation on heat transfer performance of $\mathrm{TiO}_{2}$ nanofluids in water-ethylene glycol mixture. International Communications in Heat and Mass Transfer. 2016;73:16-24.

[28] Usri NA, Azmi WH, Mamat R, Hamid KA. Forced convection heat transfer using water-ethylene glycol (60:40) based nanofluids in automotive cooling system. International Journal of Automotive and Mechanical Engineering. 2015;11:2747.

[29] Hamid KA, Azmi WH, Nabil MF, Mamat R. Improved thermal conductivity of $\mathrm{TiO}_{2-}$ $\mathrm{SiO}_{2}$ hybrid nanofluid in ethylene glycol and water mixture. IOP Conference Series: Materials Science and Engineering. 1 ed2017. p. 1-7.

[30] Nabil MF, Azmi WH, Abdul Hamid K, Mamat R, Hagos FY. An experimental study on the thermal conductivity and dynamic viscosity of $\mathrm{TiO}_{2}-\mathrm{SiO}_{2}$ nanofluids in water: Ethylene glycol mixture. International Communications in Heat and Mass Transfer. 2017;86:181-189.

[31] Hamid KA, Azmi WH, Nabil MF, Mamat R. Experimental investigation of nanoparticle mixture ratios on $\mathrm{TiO}_{2}-\mathrm{SiO}_{2}$ nanofluids heat transfer performance under turbulent flow. International Journal of Heat and Mass Transfer. 2018;118:617-627.

[32] Hemmat Esfe M, Karimipour A, Yan WM, Akbari M, Safaei MR, Dahari M. Experimental study on thermal conductivity of ethylene glycol based nanofluids containing $\mathrm{Al}_{2} \mathrm{O}_{3}$ nanoparticles. International Journal of Heat and Mass Transfer. 2015;88:728-734.

[33] Sonawane SS, Khedkar RS, Wasewar KL. Effect of sonication time on enhancement of effective thermal conductivity of nano $\mathrm{TiO}_{2}-$ water, ethylene glycol, and paraffin oil nanofluids and models comparisons. Journal of Experimental Nanoscience. 2015;10:310-322.

[34] Guo Y, Zhang T, Zhang D, Wang Q. Experimental investigation of thermal and electrical conductivity of silicon oxide nanofluids in ethylene glycol/water mixture. International Journal of Heat and Mass Transfer. 2018;117:280-286.

[35] Agarwal R, Verma K, Agrawal NK, Duchaniya RK, Singh R. Synthesis, characterization, thermal conductivity and sensitivity of $\mathrm{CuO}$ nanofluids. Applied Thermal Engineering. 2016;102:1024-1036.

[36] Nemade K, Waghuley S. A novel approach for enhancement of thermal conductivity of $\mathrm{CuO} / \mathrm{H}_{2} \mathrm{O}$ based nanofluids. Applied Thermal Engineering. 2016;95:271-274.

[37] Ho CJ, Huang JB, Tsai PS, Yang YM. Preparation and properties of hybrid waterbased suspension of $\mathrm{Al}_{2} \mathrm{O}_{3}$ nanoparticles and MEPCM particles as functional forced convection fluid. International Communications in Heat and Mass Transfer. 2010;37:490-494.

[38] Suresh S, Venkitaraj KP, Selvakumar P, Chandrasekar M. Synthesis of $\mathrm{Al}_{2} \mathrm{O}_{3}-$ $\mathrm{Cu}$ /water hybrid nanofluids using two step method and its thermo physical properties. Colloids Surfaces A. 2011;388:41-48. 
[39] Charab AA, Movahedirad S, Norouzbeigi R. Thermal conductivity of $\mathrm{Al}_{2} \mathrm{O}_{3}+\mathrm{TiO}_{2}$ /water nanofluid: Model development and experimental validation. Applied Thermal Engineering. 2017;119:42-51.

[40] Nine MJ, Batmunkh M, Kim JH, Chung HS, Jeong HM. Investigation of $\mathrm{Al}_{2} \mathrm{O}_{3^{-}}$ MWCNTs hybrid dispersion in water and their thermal characterization. Journal of Nanoscience and Nanotechnology. 2012;12:4553-4559.

[41] Toghraie D, Chaharsoghi VA, Afrand M. Measurement of thermal conductivity of $\mathrm{ZnO}-\mathrm{TiO}_{2} / \mathrm{EG}$ hybrid nanofluid. Journal of Thermal Analysis and Calorimetry. 2016;125:527-535.

[42] Megatif L, Ghozatloo A, Arimi A, Shariati Niasar M. Investigation of laminar convective heat transfer of a novel $\mathrm{TiO}_{2}$-carbon nanotube hybrid water-based nanofluid. Experimental Heat Transfer. 2016;29:124-138.

[43] Batmunkh M, Tanshen MR, Nine MJ, Myekhlai M, Choi H, Chung H, Jeong H. Thermal conductivity of $\mathrm{TiO}_{2}$ nanoparticles based aqueous nanofluids with an addition of a modified silver particle. Industrial and Engineering Chemistry Research. 2014;53:8445-8451.

[44] Madhesh D, Parameshwaran R, Kalaiselvam S. Experimental investigation on convective heat transfer and rheological characteristics of $\mathrm{Cu}-\mathrm{TiO}_{2}$ hybrid nanofluids. Experimental Thermal and Fluid Science. 2014;52:104-115.

[45] Baghbanzadeh M, Rashidi A, Rashtchian D, Lotfi R, Amrollahi A. Synthesis of spherical silica/multiwall carbon nanotubes hybrid nanostructures and investigation of thermal conductivity of related nanofluids. Thermochimica Acta. 2012;549:87-94.

[46] Baby TT, Sundara R. Synthesis and transport properties of metal oxide decorated graphene dispersed nanofluids. The Journal of Physical Chemistry C. 2011;115:85278533.

[47] Nine MJ, Munkhbayar B, Rahman MS, Chung H, Jeong H. Highly productive synthesis process of well dispersed $\mathrm{Cu}_{2} \mathrm{O}$ and $\mathrm{Cu} / \mathrm{Cu}_{2} \mathrm{O}$ nanoparticles and its thermal characterization. Materials Chemistry and Physics. 2013;141:636-642.

[48] Hamid KA, Azmi WH, Mamat R, Usri NA, Najafi G. Investigation of $\mathrm{Al}_{2} \mathrm{O}_{3}$ nanofluid viscosity for different water/EG mixture based. Energy Procedia. 2015;79:354-359.

[49] Anoop K, Sadr R, Yrac R, Amani M. High-pressure rheology of alumina-silicone oil nanofluids. Powder Technology. 2016;301:1025-1031.

[50] Abdolbaqi MK, Sidik NAC, Aziz A, Mamat R, Azmi WH, Yazid MNAWM, Najafi G. An experimental determination of thermal conductivity and viscosity of BioGlycol/water based $\mathrm{TiO}_{2}$ nanofluids. International Communications in Heat and Mass Transfer. 2016;77:22-32.

[51] Khedkar RS, Shrivastava N, Sonawane SS, Wasewar KL. Experimental investigations and theoretical determination of thermal conductivity and viscosity of $\mathrm{TiO}_{2}$-ethylene glycol nanofluid. International Communications in Heat and Mass Transfer. 2016;73:54-61.

[52] Żyła G, Fal J. Viscosity, thermal and electrical conductivity of silicon dioxideethylene glycol transparent nanofluids: An experimental studies. Thermochimica Acta. 2017;650:106-113. 
[53] Ghasemi S, Karimipour A. Experimental investigation of the effects of temperature and mass fraction on the dynamic viscosity of $\mathrm{CuO}$-paraffin nanofluid. Applied Thermal Engineering. 2018;128:189-197.

[54] Akhavan Behabadi MA, Shahidi M, Aligoodarz MR. An experimental study on heat transfer and pressure drop of MWCNT-water nano-fluid inside horizontal coiled wire inserted tube. International Communications in Heat and Mass Transfer. 2015;63:6272.

[55] Asadi M, Asadi A. Dynamic viscosity of MWCNT/ZnO-engine oil hybrid nanofluid: An experimental investigation and new correlation in different temperatures and solid concentrations. International Communications in Heat and Mass Transfer. 2016;76:41-45.

[56] Soltani O, Akbari M. Effects of temperature and particles concentration on the dynamic viscosity of MgO-MWCNT/ethylene glycol hybrid nanofluid: Experimental study. Physica E: Low-dimensional Systems and Nanostructures. 2016;84:564-570.

[57] Akilu S, Baheta AT, Sharma KV. Experimental measurements of thermal conductivity and viscosity of ethylene glycol-based hybrid nanofluid with $\mathrm{TiO}_{2-}$ $\mathrm{CuO} / \mathrm{C}$ inclusions. Journal of Molecular Liquids. 2017;246:396-405.

[58] Shahsavar A, Bahiraei M. Experimental investigation and modeling of thermal conductivity and viscosity for non-Newtonian hybrid nanofluid containing coated $\mathrm{CNT} / \mathrm{Fe}_{3} \mathrm{O}_{4}$ nanoparticles. Powder Technology. 2017;318:441-450.

[59] Chandrasekar M, Suresh S, Senthilkumar T. Mechanisms proposed through experimental investigations on thermophysical properties and forced convective heat transfer characteristics of various nanofluids - A review. Renewable and Sustainable Energy Reviews. 2012;16:3917-3938.

[60] Sommers AD, Yerkes KL. Experimental investigation into the convective heat transfer and system-level effects of $\mathrm{Al}_{2} \mathrm{O}_{3}$-propanol nanofluid. Journal of Nanoparticle Research. 2010;12:1003-1014.

[61] Ho CJ, Liu WK, Chang YS, Lin CC. Natural convection heat transfer of aluminawater nanofluid in vertical square enclosures: An experimental study. International Journal of Thermal Sciences. 2010;49:1345-1353.

[62] Heyhat MM, Kowsary F, Rashidi AM, Alem Varzane Esfehani S, Amrollahi A. Experimental investigation of turbulent flow and convective heat transfer characteristics of alumina water nanofluids in fully developed flow regime. International Communications in Heat and Mass Transfer. 2012;39:1272-1278.

[63] Nabati Shoghl S, Jamali J, Keshavarz Moraveji M. Electrical conductivity, viscosity, and density of different nanofluids: An experimental study. Experimental Thermal and Fluid Science. 2016;74:339-346.

[64] Akilu S, Sharma KV, Baheta AT, Mamat R. A review of thermophysical properties of water based composite nanofluids. Renewable and Sustainable Energy Reviews. 2016;66:654-678.

[65] Zhou SQ, Ni R. Measurement of the specific heat capacity of water-based $\mathrm{Al}_{2} \mathrm{O}_{3}$ nanofluid. Applied Physics Letters. 2008;92:093123.

[66] O'Hanley H, Buongiorno J, McKrell T, Hu L-w. Measurement and model validation of nanofluid specific heat capacity with differential scanning calorimetry. Advances in Mechanical Engineering. 2012;4:181079. 
[67] Barbés B, Páramo R, Blanco E, Pastoriza Gallego MJ, Piñeiro MM, Legido JL, Casanova C. Thermal conductivity and specific heat capacity measurements of $\mathrm{Al}_{2} \mathrm{O}_{3}$ nanofluids. Journal of Thermal Analysis and Calorimetry. 2013;111:1615-1625.

[68] Nuim Labib M, Nine MJ, Afrianto H, Chung H, Jeong H. Numerical investigation on effect of base fluids and hybrid nanofluid in forced convective heat transfer. International Journal of Thermal Sciences. 2013;71:163-171.

[69] Sekhar YR, Sharma KV. Study of viscosity and specific heat capacity characteristics of water-based $\mathrm{Al}_{2} \mathrm{O}_{3}$ nanofluids at low particle concentrations. Journal of Experimental Nanoscience. 2015;10:86-102.

[70] Yiamsawasd T, Dalkilic AS, Wongwises S. Measurement of specific heat of nanofluids. Current Nanoscience. 2012;8:939-944.

[71] Vajjha RS, Das DK. Specific heat measurement of three nanofluids and development of new correlations. Journal of Heat Transfer. 2009;131:071601-071601-7.

[72] Dawood HK, Mohammed HA, Che Sidik NA, Munisamy KM, Wahid MA. Forced, natural and mixed-convection heat transfer and fluid flow in annulus: A review. International Communications in Heat and Mass Transfer. 2015;62:45-57.

[73] Hatami N, Kazemnejad Banari A, Malekzadeh A, Pouranfard AR. The effect of magnetic field on nanofluids heat transfer through a uniformly heated horizontal tube. Physics Letters A. 2017;381:510-515.

[74] Azari A, Derakhshandeh M. An experimental comparison of convective heat transfer and friction factor of $\mathrm{Al}_{2} \mathrm{O}_{3}$ nanofluids in a tube with and without butterfly tube inserts. Journal of the Taiwan Institute of Chemical Engineers. 2015;52:31-39.

[75] Mwesigye A, Huan Z. Thermodynamic analysis and optimization of fully developed turbulent forced convection in a circular tube with water- $\mathrm{Al}_{2} \mathrm{O}_{3}$ nanofluid. International Journal of Heat and Mass Transfer. 2015;89:694-706.

[76] Andreozzi A, Manca O, Nardini S, Ricci D. Forced convection enhancement in channels with transversal ribs and nanofluids. Applied Thermal Engineering. 2016;98:1044-1053.

[77] Yang C, Peng K, Nakayama A, Qiu T. Forced convective transport of alumina-water nanofluid in micro-channels subject to constant heat flux. Chemical Engineering Science. 2016;152:311-322.

[78] Ho CJ, Chang CY, Yan WM. An experimental study of forced convection effectiveness of $\mathrm{Al}_{2} \mathrm{O}_{3}$-water nanofluid flowing in circular tubes. International Communications in Heat and Mass Transfer. 2017;83:23-29.

[79] Azmi WH, Usri NA, Mamat R, Sharma KV, Noor MM. Force convection heat transfer of $\mathrm{Al}_{2} \mathrm{O}_{3}$ nanofluids for different based ratio of water:ethylene glycol mixture. Applied Thermal Engineering. 2017;112:707-719.

[80] Khdher AM, Sidik NAC, Hamzah WAW, Mamat R. An experimental determination of thermal conductivity and electrical conductivity of bio glycol based $\mathrm{Al}_{2} \mathrm{O}_{3}$ nanofluids and development of new correlation. International Communications in Heat and Mass Transfer. 2016;73:75-83.

[81] Mahmoudi M, Tavakoli MR, Mirsoleimani MA, Gholami A, Salimpour MR. Experimental and numerical investigation on forced convection heat transfer and pressure drop in helically coiled pipes using $\mathrm{TiO}_{2} /$ water nanofluid. International Journal of Refrigeration. 2017;74:627-643. 
[82] Qi C, Wan YL, Li CY, Han DT, Rao ZH. Experimental and numerical research on the flow and heat transfer characteristics of $\mathrm{TiO}_{2}$-water nanofluids in a corrugated tube. International Journal of Heat and Mass Transfer. 2017;115:1072-1084.

[83] Azmi WH, Sharma KV, Sarma PK, Mamat R, Najafi G. Heat transfer and friction factor of water based $\mathrm{TiO}_{2}$ and $\mathrm{SiO}_{2}$ nanofluids under turbulent flow in a tube. International Communications in Heat and Mass Transfer. 2014;59:30-38.

[84] Hekmatipour F, Akhavan Behabadi MA, Sajadi B. Combined free and forced convection heat transfer of the copper oxide-heat transfer oil (CuO-HTO) nanofluid inside horizontal tubes under constant wall temperature. Applied Thermal Engineering. 2016;100:621-627.

[85] Sheikholeslami M, Bhatti MM. Forced convection of nanofluid in presence of constant magnetic field considering shape effects of nanoparticles. International Journal of Heat and Mass Transfer. 2017;111:1039-1049.

[86] Ranjbarzadeh R, Meghdadi Isfahani AH, Afrand M, Karimipour A, Hojaji M. An experimental study on heat transfer and pressure drop of water/graphene oxide nanofluid in a copper tube under air cross-flow: Applicable as a heat exchanger. Applied Thermal Engineering. 2017;125:69-79.

[87] Zainal Abidin S, Mohamad IS, Bani Hashim AY, Abdullah N, Hafiz MIM, Masripan $\mathrm{NAB}$, Abdullah A. Investigation of thermal characteristics of CNF-based nanofluids for electronic cooling applications. Journal of Mechanical Engineering and Sciences. 2016;10:2336-2349.

[88] Minakov AV, Guzei DV, Meshkov KN, Popov IA, Shchelchkov AV. Experimental study of turbulent forced convection of nanofluid in channels with cylindrical and spherical hollows. International Journal of Heat and Mass Transfer. 2017;115:915925.

[89] Sheikholeslami M, Vajravelu K, Rashidi MM. Forced convection heat transfer in a semi annulus under the influence of a variable magnetic field. International Journal of Heat and Mass Transfer. 2016;92:339-348. 